\title{
Looking backward and forward: Political Links and Environmental Corporate Social Responsibility in China
}

\begin{abstract}
This study aims to enrich our understanding of the relationship between political connections and the adoption of environmental corporate socially responsible (ECSR) investments. In addition to the individual-level political connections, i.e., entrepreneurs' personal ties to government officials, we propose in China the creation of Communist Party of China (CPC) branches in privately-owned firms serve as organizational and institutionalized dimensions of political connection building. Drawing on the social exchange theory, this paper details how $\mathrm{CPC}$ branches function in privately-owned firms and how entrepreneurs are motivated by the reciprocal logic to engage in ECSR. We also supplement this main effect by examining the boundary conditions of it at the firm- and regional-level. Using a dataset with 17,690 firm observations in China, we find that the existence of CPC branches gives rise to the ECSR investments and the firm-level contingencies such as centralized governance and financial constraints, and the regional-level contingencies such as the development of the market system, are important moderators that shape the association of political links and ECSR investments. These findings have ample implications to understand the ECSR activities and extend social exchange theory beyond the individual level on which it is typically applied.
\end{abstract}

Keywords: Environmental Corporate Social Responsibility (ECSR); Political Connections; Party Branch; Governance Structure; Financial Constraints; Emerging Economy; Social Exchange Theory 


\section{Introduction}

Political connections play an important role in corporate social responsibility (CSR) of a firm (Cumming et al. 2016; Muttakin et al. 2018; Li et al. 2015; Lin et al. 2015). Present studies have focussed on the role of individual-level political connections (i.e., political ties between entrepreneurs and government officials) and presented contradictory predictions. We have a limited understanding of the link between political connections at the organizational level and CSR. In this study, we draw on a recently introduced initiative launched by the Central Committee of Communist Party of China (CPC) that encourages the creation of a CPC branch $^{1}$ in privately-owned firms, which may transform individual-level political connections to the organizational-level in privately-owned firms. Our setting is particularly interesting since government relationships and political connections are of significance for privatelyowned firms in emerging economies such as China (Arnoldi and Muratova 2018; Faccio et al. 2006; Peng and Luo 2000). A policy from the Central Committee of CPC encouraging the creation of in-house CPC branches offers the opportunity to examine how organizationallevel political connections matter to CSR investments.

A second motivation for this study is that previous studies have not distinguished between legally binding CSR investments (i.e. obligatory CSR) and non-obligatory or voluntary CSR investments. Particularly in economies where there is more political and state influence, the general direction of policies of the government may have much more effect on firm investments than we would expect in more market-based settings. China has called for significant environmental investments to clean its air, water, and rivers from high pollution (Shi and Xu 2018; Wei at al. 2017; Xu 2011). For instance, the central government included

\footnotetext{
${ }^{1}$ Party branch (jiceng dangzuzhi) is the smallest unit of Chinese Communist Party (CCP) at the grassroots level. One of the unique characteristics of CCP is its "mass line" (qunzhong luxian) (Han 2015). In other words, CCP relays on numerous party branches to exercise its control over the state, economy and society in China.
} 
an environmental policy by setting a $10 \% \mathrm{SO} 2$ reduction target at the first time in the tenth Five-Year Plan (2001-2005) (Xu 2011; Shi and Xu 2018). ${ }^{2}$ In 2006, the State Council promulgated a regulation titled "Reply to Pollution Control Plan during the Eleventh FiveYear Plan", which called for investments to tackle the environmental pollution at the provincial level. These evidence shows that the $\mathrm{CPC}$ has declared environmental investments a priority, but we know much less under what contingencies firms are engaging with these aims. As such, this paper focuses on non-obligatory environmental corporate social responsibility $\left(\mathrm{ECSR}^{3}\right)$ investments. Non-obligatory investments have been argued i) in the more economically oriented literature to be driven by long-term benefits for the firm or ii) in the CSR literature to be driven by ethical or philanthropic motives (Carroll 1991).

A third motivation for this study is that the boundary conditions of the links between political connections and ECSR investment have obtained limited attention (Dong et al. 2016). Several studies have distinguished firm types to better understand their CSR investments, but have not looked at contingencies within the same type of firms. For example, Lin et al. (2015) demonstrated that political connections are more likely to drive CSR activities in non-state-controlled firms, smaller firms, and firms operating in cities ruled by a more corrupt government. Li et al. (2015) also found that there is a stronger relationship between political connections and corporate philanthropy in non-state-owned firms. The studies miss to explore how intra-firm characteristics (e.g., corporate governance and

\footnotetext{
${ }^{2}$ China's five-year plans are a series of countrywide social and economic development initiatives containing detailed guidelines for economic and social development. The tenth Five-Year Plan (2001-2005) was the first to include an environmental policy by setting a 10\% SO2 reduction target. In the eleventh Five-Year Plan (2006-2010), the central government establishes a pollution reduction target $10 \%$ for the entire country with different provinces sharing different burdens. In 2006, the China State Council issued a document named "Reply to Pollution Control Plan During the Eleventh Five-Year Plan", which handed down national goal to pollution reduction targets in provincial level. Formal contracts for the provincial pollution reduction targets were signed by the provincial vice presidents.

${ }^{3}$ In this project, ECSR refers to a firm's voluntary environmental investment, including investment in sewage treatment, air pollution treatment, soil pollution treatment, solid waste treatment, flue gas treatment, waste recycling and so on. These investments are not obligated. In other words, there is no explicit government policy which forces firms to invest in these items, but our data shows that some firms scarify their private benefits to do so.
} 
financial conditions) and regional characteristics (e.g., development of the market economy) affect the relationship between political connections and ECSR.

To address these gaps, this paper aims to explore the following two questions: How do organizational-level political connections affect entrepreneurs' non-obligatory ECSR investments? What are the key contingencies that affect the implications of such political connections on ECSR? We define entrepreneurs for the purpose of this study as owners of privately-owned firms in which they hold more than half of the equity share. As such, the decisions of the entrepreneur are likely to converge with those made on the firm-level (Zhao and Lu 2016). Non-obligatory ECSR investments are investments that go beyond the legal requirements "to contribute to a better society and cleaner environment (OECD 2001)". The literature on corporate social responsibility (CSR) has moved from an initial social focus (Carroll 1999) to increasingly include the environment as a second core factor (Dahlsrud 2008). A focus on the environmental aspect seems appropriate as it differs conceptually from the social challenges due to the institutional environment (Matten and Moon 2008) and is most timely during an ever-increasing urge to tackle climate change. In addition, political connections have often been overlooked in the ECSR literature, for example, the work of Babiak and Trendafilovia (2011) on motivations for ECSR.

We use social exchange theory to address the questions. Social exchange theory explains exchanges and how they happen. It also helps analysing relationships formed on the basis of social exchanges (Cropanzano and Mitchell 2005; Emerson 1976). Often, exchanges underlie the idea of reciprocity in some forms. The setting created by entrepreneurs and their CPC party branches fits such patterns well. Much of the literature on social exchange theory has discussed individual exchanges rather than exchanges between individuals and organizational entities. In this paper, however, we are going to approach the exchanges between individuals (i.e., entrepreneurs) and organizational entities (i.e., CPC branches in privately-owned firms). 
In addition, most of the social exchange theory has evolved around economic exchanges. In our setting, other forms may play a role, for example, information, power or philanthropy.

We tested our theoretical framework by looking at 17,690 observations of a random sample of firms. We find that the existence of CPC branches gives rise to the ECSR investments and the firm-level contingencies such as centralized governance and financial constraints, and the regional-level contingencies such as the development of the market system, are important moderators that shape the association of political links and ECSR investments.

Our study contributes to the literature in three ways. First, we shed new light on the association of political connections and ECSR. We explore a contingency model of the effects of an organizational level political connection (i.e., the creation of CPC branches) on ECSR and how these effects vary according to different organizational and regional factors, greatly enriching our understanding of how and when political connections matter to CSR. We focus our attention on the ECSR because this dimension of CSR deserves particular attention due to its nature and the extent of the challenge that it addresses (e.g. with reference to the debate on climate change). While ECSR appears a pertinent issue, the role of political connections for commercial decision-making in this context is underexplored (Babiak and Trendafilovia 2011).

Second, we extend the CSR literature by clearly distinguishing non-obligatory and obligatory ECSR investments. While in accounting research, we find a study on voluntary disclosure (e.g., Graham et al. 2004), this idea has not readily been transferred to the management literature. However, this distinction is helpful for disentangling some of the motivations underlying CSR investments. Our study is particularly suitable to make this argument as our setting can clearly distinguish between these two kinds of investments. 
Third, our study contributes to the social exchange theory. Social exchange theory has primarily focused on theorizing exchanges between two people. Despite calls for studies that extend the scope of the theory, there is very limited literature that has applied social exchange theory beyond individual-level settings (Cropanzano et al. 2017). We extend the social exchange theory by using it to explicate the exchanges between individuals (i.e., entrepreneurs) and organizational entities (i.e., party branches in privately-owned firms). A strength of our study is the focus on entrepreneurs who own (by majority share) their firms and thus are able to interact with the CPC branches in their firms. Such a setting facilitates us to approach the social exchange theory in a unique way and extend its applications.

The remainder of this paper is organized as follows. We briefly review relevant literature streams and build our hypotheses. Then, we introduce our empirical setting and method before reporting the results. Finally, we discuss the results and the limitations of the study before concluding with the takeaways of this study.

\section{Theory and hypotheses}

We adopt the social exchange theory to build our argument. According to this theory, exchanges are motivated by reciprocity (Cropanzano et al. 2017; Cropanzano and Mitchell 2005). Reciprocity comes in different forms (economic, cultural etc.), as indirect, direct, or possibly third-party reciprocity. In our setting, the exchange happened between entrepreneurs and the CPC party in their firms. We detail how CPC branches function in privately-owned firms and how entrepreneurs are motivated by the reciprocal logic to engage in ECSR.

\section{Political connections and non-obligatory ECSR investments}

In emerging economies, institutions are often shaped in a co-creation process between the government/ruling party and firms in which firms help writing regulations, policies and laws 
(Xing et al. 2018). Some firms even live off following and exploiting these regulations and policies (Dai and Liao 2018). In such settings, entrepreneurs have strong incentives to maintain good relations to the government and/or the CPC (Li et al. 2008; Peng and Luo 2000). The study by Hilman et al. (2004) shows that political connections are strategically used to gain competitive advantage. As a result, political connections are pervasive in emerging economies and frequently discussed in the management literature (Luo et al. 2018; Tihanyi et al. 2019).

In addition to entrepreneurs' personal ties to government officials, one types of individual-level political connections, prior research has treated the establishment of CPC branch in private firms as a measure of political connection as well (e.g., Dong et al. 2016). Indeed, these branches are the grassroots of CPC, which link privately-owned firms and the party-state in an organic manner. CPC branches institutionalize the firm's involvement in the institutional shaping process (Yan and Jie 2017). The motivation of the CPC to set up CPC branches in privately-owned firms is to ensure that these firms are under the "correct" directions (Dong et al. 2016; Yan and Jie 2017). Additionally, the CPC relies on these branches to encourage the participation and support of privately-owned firms in terms of mobilizing resources for social issues and the public good if necessary (Sun and Wright 2012). Typically, these social issues include environmental protection, deterioration, and social issues relating to work conditions. The latter tend to be closer handled by the unions while the former is one of the central aspects that firms are frequently called on to help; often on a non-obligatory basis.

To fulfill such objectives, the CPC branches in privately-owned firms strive all out to assist the entrepreneurs to develop their businesses in that they are aware that the privatelyowned firms are not able to shoulder the social responsibilities until they achieve a sound economic development goal (Dong et al. 2016). The entrepreneurs in privately-owned firms 
may even feel that a creation of CPC branch is unwise if it is not of help in achieving economic success. After all, running a CPC branch in their own firms is resource-consuming even though higher-level CPC organizations (i.e., local Committees of the CPC) supply considerable resources to these Party branches. The CPC branches in privately-owned firms understand that they will have the space to survive only when they are able to contribute to the economic development of the privately-owned firms in which they are embedded. As a result, the CPC branches try their best to assist these firms by actively offering their advice to entrepreneurs and by guiding the employees to devote their time and efforts to critical issues that are facing privately-owned firms.

Indeed, the CPC branches can substantially contribute to privately-owned firms for two reasons. On the one hand, each CPC branch is under the supervision of local Committees of the CPC, which is closely linked to local government (for the organization of CPC branches, please refer to Dong et al. (2016)). Accordingly, the CPC branches are well-informed of the current agenda of local government and the government policies, which are valuable to privately-owned firms especially in the emerging market setting (Dai and Liao 2018). On the other hand, the leaders of $\mathrm{CPC}$ branches receive training from their upper organizations on how to accelerate the development of privately-owned firms by nurturing positive organizational culture, boosting the innovative and entrepreneurial spirits among employees as well as maintaining the employees' morale. These aspects may truly spur the development of privately-owned firms in promising directions.

In viewing these positive "spillovers" created by the CPC branches, entrepreneurs may feel that they are greatly benefited from the CPC. In return, they feel they need to "do something" to pay back the positive inputs by these CPC branches. We posit that it is a social exchange or reciprocity logic that shapes the interactions between entrepreneurs and CPC branches in their firms (Cropanzano and Mitchell 2005; Emerson 1976). Entrepreneurs may 
thus echo to the calls from the CPC voluntarily and actively. As have mentioned, the goals of CPC involve not only economic developments, but also social developments and welfare provisions. The party-state cannot manage the latter as a lone player, but needs the buy-in of firms (Scherer et al. 2014). Those privately-owned firms that have achieved economic success with the assistance of their in-house Party apparatus may align with the CPC's social goals and thus engage in such activities as doing ECSR voluntarily (Frynas ad Stephens 2015). Indeed, ECSR has been at the forefront of improving the environmental conditions in China (Wei at al. 2017).

In addition to such "backward looking", entrepreneurs may also "look forward". That is, they may realize that their interactions with the CPC branches is a long-term game and that alignment with the CPC and doing good for the society may trigger the CPC and their inhouse organizations (i.e., the CPC branches) to devote more resources and efforts to their firms' development in the future (Lin et al. 2015). After all, the CPC controls a range of critical resources via its government system such as land distribution, much of the banking sector, regulations across industries (Dong et al. 2016). In the context of the emerging market, firms rely on access to these resources for the prosperity of their businesses (Fischer and Reuber 2010). In addition, the CPC branches are really able to function as an "engine" for their firms. In sum, entrepreneurs may act even more voluntarily if they view their actions in the long-term. We label this effect as the future rewarding logic.

Taken together, entrepreneurs may look backward as well as look forward simultaneously in viewing CPC branches in their firms and respond positively to engage in ECSR. We thus propose the following hypothesis:

H1: Privately-owned firms with CPC branch bear more ECSR investments than those without. 


\section{Firm- and regional-level contingencies}

The extent to which a CPC branch executes its influence on a privately-owned firm and can foster one of the central CPC goals such as ECSR investments is likely mitigated by the number of stakeholders and goal alignment in a firm (March and Cyert 1963). This is because entrepreneurs' willingness to reciprocate in terms of committing to the CPC party goals will be suppressed by the multiple stakeholders who may have differing interests and time horizons.

Prior research has looked at the degree of centralization of governance for decisionoutcomes. Many of these follow the resource dependence logic (Pfeffer and Salancik 1978). Zhao and Lu (2016), for instance, find that firms with more governance mechanisms seem to have more difficulties in making use of political capital. Many private firms have a diverse base of stakeholders with often unaligned or unclear interests (Tang and Tang 2012). In such a situation, any decision-making will be more complex and the CPC branch as an additional stakeholder may have limited influence over the decision-making process and the alignment process of the different stakeholders' interests. Although entrepreneurs are the main decisionmakers in our sample of Chinese privately-owned firms (Lu and Zhao 2016), they may still need to consider the differing interests of others. Some shareholders may be short-term oriented and the engagement of ECSR may not be in line with their interests. In such a scenario, it may be hard for entrepreneurs to follow the CPC goals and non-obligatory ECSR investments may become less likely to be a shared goal of the majority of stakeholders, let along executing such investments.

Firms with a single decision-maker, in contrast, may follow the reciprocity logic to do the ECSR investments more easily (Cropanzano et al. 2017). Firms with single decisionmakers that benefited from adopting a CPC branch are likely to commit to the initiatives 
launched by the CPC branch, as otherwise, entrepreneurs would feel guilty and unease (Cropanzano and Mitchell 2005; Emerson 1976). While privately-owned firms with multiple stakeholders may have decision-making processes that have to align the interests of a diversity of stakeholders, firms with single decision-makers may adopt a much more strategic role when it comes to the voluntary adoption of ECSR investments.

To summarize, the existence of centralized governance (i.e., entrepreneurs hold the majority power of decision making) may better translate her/his willingness and voluntary to reciprocal into concrete investments that are in line with the CPC's goals and expectations. We thus propose the following hypothesis:

H2: The positive association between CPC branch and ECSR is strengthened in firms with centralized governance.

We suggest that financial constraints are another firm-level contingency that is able to shape the link between CPC branch and ECSR. The ethical ECSR investor may act more cautiously in a low munificence environment. As Chen et al. (2017) argue, entrepreneurs/firms in munificent environments are more likely to behave environmentally responsible. The reciprocity on the part of an entrepreneur to engage in ECSR could be affected by differing levels of internal financial munificence because the financial slack is a precondition of voluntary investments (Julian and Ofori-Dankwan 2013). Allocating resources from privately-owned firms in times of crisis or low earnings to - in the short-term non-essential task - goes against the nature of the interests of any stakeholder. For example, the financial crisis may pose significant challenges to privately-owned firms that in turn are less likely to invest in initiatives peripheral to their core business. Privately-owned firms may deploy their resources to mitigate the negative impact of urgent issues. Accordingly, the slack resources of the firm shrink. In such a scenario, entrepreneurs' motivation to do ECSR 
investments will decrease. Hence, entrepreneurs may not undertake as many ECSR activities as in less constraint times even when feeling indebted to their CPC branches as well as anticipating possible future returns from the CPC.

In sum, the implementation of ECSR depends not only on the willingness of entrepreneurs to reciprocate but also on the financial situations of their firms. This leads us to predict that the influence of CPC branches in private firms on ECSR hinges on the firms' financial constraints. We propose the following hypothesis:

\section{H3: The positive association between CPC branch and CSR is weakened in a high}

\section{financial constraint environment.}

The implications of CPC branches on ECSR may be different in various regions. Differences between regions are often characterized by the degree of market development (Gao and Hafsi 2015; Sun et al. 2014). Higher market-orientation comes a better infrastructure (i.e., legal, etc.) for businesses and less government intervention (Zhou and Poppo 2010). In these more marketized regions, privately-owned firms are able to develop prosperously and account for the majority of the local economy (Kafouros and Aliyev 2016). In such a setting, we expect the association between CPC branch and ECSR investment to be more pronounced.

As we have articulated before, one factor influencing voluntary ECSR investments in our setting is the potential "paybacks" from the party-state in the future for doing these investments today. In our setting, the potential payback actions of the CPC for reciprocating voluntary contributions to the goals of the $\mathrm{CPC}$ are provision of critical resources at the control of government and/or CPC, which are of importance in terms of privately-owned firms' growth and development (Peng and Luo 2000; Li et al. 2008). While the CPC/government holds a considerable amount of resources, the portion allocated to the 
private sector has a maximum limit. As mentioned above, the private sector usually accounts for a larger proportion of the economy in market developed regions and thus tends to involve more privately-owned firms. As a result, the competition for these valuable opportunities and resources from the $\mathrm{CPC} /$ government among privately-owned firms arises inevitably in these regions. Privately-owned firms, in view of the potential "paybacks" from the CPC/government and spurred by the competitions among peers (Gao and Hafsi 2015), are thus actively aligned with CPC goals (for example through a CPC branch) and engage in ECSR investment to favor the government/ruling party.

Accordingly, we expect to see stronger relationships between CPC branch and ECSR investments in market-oriented regions due to the competitive nature of winning the future benefits of payback from voluntary ECSR investments. We thus propose the following hypothesis:

H4: The positive association between CPC branch and ECSR is strengthened in more market-oriented regions.

Figure 1 summarized all the hypotheses we proposed above.

[Insert Fig. 1 about here] 


\section{Method}

\section{Sample and Data}

Our main data source is the Chinese Private Enterprises Survey (CPES). The CPES conducted by the Privately-Owned Enterprises Research Project Team ${ }^{4}$ is one of the longestrunning and large-scale ongoing national sample surveys in China. Such a large-scale survey endorsed by the government is designed to collect information from the Chinese private sector to facilitate the central government's policy-making processes.

The survey is carried out every two years, and so far, it has been conducted for 13 times in 1993, 1995, 1997, 2000, 2002, 2004, 2006, 2008, 2010, 2012, 2014, 2016 and 2018 respectively. So far, the data from 1993-2012 are open to researchers for academic use; the data for 2014 is available conditionally, and the rest are unavailable. We get the authorization from Research Center for Private Enterprises at Chinese Academy of Social Sciences (PCPECASS) to use this series of the survey.

The dataset is by far the best one for studying the private business owners and privatelyowned firms in China ${ }^{5}$. It contains several parts: the characteristics of the entrepreneurs (e.g., education and political affiliation) and the characteristics of the firm (e.g., age, size, investment, political action, etc). The information on CSR becomes available since 2006,

\footnotetext{
${ }^{4}$ Member organizations include All-China Federation of Industry and Commerce, State Administration for Market Regulation, Chinese Academy of Social Sciences, the China Society of Private Economy, and the United Front Work Department of CCP

${ }^{5}$ According to the project team, to make the survey be representative to the population of nationwide registered private firms, a stratified random sampling procedure is applied. The stratifications include locations, industries, stages of economic development, and distribution of the private firms in urban and rural areas within each location (a city or a county). The original sample frame for this survey is a modified version of the private enterprise section sample frame used for its annual data collection by the China State Bureau of Statistics, which is considered to be representative of all registered private enterprises in China. In particular, the sampling involved two stages. In the first stage, a pre-specified number of counties were selected in each province based on economic development levels, so that both developed and less developed counties were represented. In the second stage, a pre-specified number of private firms were selected in each county based on location and primary industrial sector. Both urban and rural firms were chosen; and within each urban/rural area, firms from all industrial sectors were sampled. The number of sampled firms in each province, county, urban/rural area, and sector was proportionate to the population size of the private enterprises in each of these categories.
} 
which allows us to explore the motivations of why entrepreneurs / decision-makers may invest in ECSR in China.

The surveys covered all provinces and over one-third of the cities in China, and the average sample size is around 3,000 for each survey. For example, the sample which could be used for the regression analysis of the 2006 survey includes 2579 privately-owned firms located in 100 cities; 3103 privately-owned firms located in 141 cities for the 2008 survey, 3437 privately-owned firms located in 142 cities for the 2010 survey, 3927 privately-owned firms located in 158 cities for the 2012 survey, and 4645 privately-owned firms located in 200 cities for the 2014 survey. We thus constructed a pooled cross-section dataset containing 17,690 firm observations. Table 1 shows that these sample firms were drawn from 31 provinces in China. And the distribution of the sample firms is in accordance with the private sector development in various regions, thus indicating the representative of these sample firms. Table 1 also presents the yearly distribution of the industries to which these private firms belong. It shows that most of the privately-owned firms in our sample are concentrated in manufacturing, construction, wholesale and retail industries. This also coincides with the fact that most of the privately-owned firms are in the labour-intensive sectors in China.

[Insert Table 1 about here]

\section{Dependent variable}

ECSR (EnInvest, InEnInvest): We are interested in whether the existence of CPC branch shapes privately-owned firms' CSR activities especially those related to environmental protection. We thus use privately-owned firms' voluntary environmental investments as CSR 
investment. To make sure that our results are robust enough, we measure it in two different ways. To capture the firm's willingness to engage in the environmental CSR, we firstly generate EnInvest, a dummy variable, which equals to one if the firm has environmental investment at the time of the survey and equals to zero otherwise. To measure the extent of environmental CSR, we further generate InEnInvest, the log transformation of the environmental investments.

\section{Independent variable}

CPC branch (PB): To estimate the effects of the Party branch on CSR, we generate the "Party branch (PB)" variable. As a dummy variable, it is equal to one if a focal firm has already set up a CPC branch within the firm in the surveyed year, and it is equal to zero otherwise.

\section{Moderator}

Central Governance (CenGovern): The moderator in $\mathrm{H} 2$ will be used to measure whether the entrepreneur has the dominant power in the decision-making process in a firm. We construct a dummy variable, CenGovern, and it is equal to one if the entrepreneur reported himself/herself in the survey that he/she was the final decision-maker.

Financial Constraint (FC): FC is the moderator for $\mathrm{H} 3$ which equals one if the firm does not pay any dividend in the survey year. Fazzari et al. (1988) argue that financially constrained firms are less likely to pay a dividend to their investors. ${ }^{6}$

\footnotetext{
${ }^{6}$ As a robustness check, we construct two variables to proxy the firm's financial environment based on the firm's basic characteristics: 1) Following Campello et al. (2010), we treated the financial crisis in 2008 as an external financial constraint shock for firms. FC1 equals to one if the time of the survey is 2010, and it equals to zero, otherwise; 2) FC2 equals to one if firms with the HP index higher than the average, otherwise zero. Prior studies show that small and young firms are more likely to suffer financial constraint. We constructed the HP Index, following Hadlock and Pierce (2010), as $-0.737 *$ Size + $0.043 *$ Size $2-0.040 *$ Age, where Size equals the log of sales, and Age is the number of years the firm is established. The results of our robustness check are available on request.
} 
Market Orientation (MarOrient): Following Li et al. (2008), we use the proportion of total fixed investment in a province that comes from privately-owned firms as the moderator to measure the regional level of market orientation in H4. A higher value of the variable, MarOrient, indicates a better development of the market system. These data come from the Bureau of Statistics of China.

\section{Control variable}

We included several control variables that influence firms' CSR into our regression models as well. Entrepreneurs' political connection may affect the firms' CSR (Lin et al. 2015), so we control entrepreneurs' current political connections and political capital. Following Lu and Zhao (2016), Jia (2014) and Guo et al. (2014), we include the following variables to our model: 1) Party member, a dummy variable that equals to one if the firm's owner is a member of the CPC at the time of survey and equals to zero if otherwise; 2) Prior_gov_job, a dummy variable that equals to one if the firm's owner used to work for either the government or the CPC before founding the firm and equals to zero if otherwise; 3) PC, a dummy variable that equals to one if the firm's owner is a member of the People's Congress at the time of survey and equals to zero if otherwise; 4) CPPCC, a dummy variable that equals to one if the firm's owner is a member of the People's Consultative Conference at the time of survey and equals to zero if otherwise.

We also control the entrepreneur's gender (Gender) and age (CEO_age). Entrepreneur's education background is measure by another dummy variable, Edu_dummy, and it equals to one if the entrepreneur has obtained a bachelor's degree or above at the time of the survey year and equals to zero if otherwise. As suggested by Lepoutre and Heene (2006) and Cheung et al. (2012), the firm's size, profitability and CSR performance are correlated with each other, so we use the log value of its total sales to measure the firm's size 
(Size_sales), and use the ratio of net profit over sales to measure the firm's profitability (ROS). Firms' age (Firm_age) was controlled for as well.

The summary statistics of all variables are presented in Table 2, and the pairwise correlation matrix among these variables is presented in Table 3. On average, $34.5 \%$ of the sample firms have invested in ECSR, and on average they invested 158170 RMB every year to protect the environment. In our sample, $33.1 \%$ of the firms already had set up the CPC branches in their firm. Currently, $24.1 \%$ of the entrepreneurs are a member of PC, and $30.4 \%$ of the entrepreneurs are a member of CPPCC. Also, about $35.8 \%$ of the entrepreneurs are CPC members; and $16.6 \%$ of the entrepreneurs are had been government officials before they set up their businesses. Moreover, as high as 57\% the entrepreneurs hold a bachelor's degree or above.

[Insert Table 2 and Table 3 about here]

\section{Results}

Table 4 presents the univariate tests between firms with and without the $\mathrm{CPC}$ branch, and the t-statistics shows preliminary evidence that supports our H1 that privately-owned firms with the CPC branch engage in more ECSR no matter which measures of ECSR is used. It also shows that the entrepreneurs of firms with CPC branches are more likely to have a political connection and political capital, and these firms are larger and older, so it is important to control both firm-level and entrepreneur-level characteristics in our empirical models. 
[Insert Table 4 about here]

To examine whether the adoption of CPC branch affects the privately-owned firms' ECSR performance, hierarchical linear models $^{7}$ (firm level and regional level) with industry and year fixed effect controlled is implemented when the dependent variable is LnEnInvest, and hierarchical nonlinear model is used when the dependent variable is EnInvest. The estimation results are presented in Table $5 .^{8}$ The coefficients of Party branch (PB) in Model (1) and (2) are both positively significant at $0.1 \%$ level, suggesting that the adoption of the Party branch will significantly increase the willingness and the extent of the firm's ESCR investment. Specifically, we find that: the probability of investing in ECSR will increase by $10.5 \%$ if the privately-owned firm already sets up the Party branch (PB); The ECSR investment will be RMB 26,914 higher for the firm with the Party branch (PB). In all, Table 6's Model (1) and (2) support Hypothesis 1 that privately-owned firms with Party branch (PB) bear more ECSR.

\footnotetext{
${ }^{7}$ We thank the anonymous reviewer for pointing out that hierarchical linear model (HML) is more appropriate for our nested data (firms within regions) than the OLS model. Although both our independent variable (PB) and dependent variable (ECSR) are at the firm level, one of our moderators is at the provincial level. According to Hofmann (1997), hierarchical linear models provide a conceptual and statistical mechanism for investigating and drawing conclusions regarding the influence of phenomena at different levels of analysis.
}

Our HML models consisted of two levels. At level 1, the unit of analysis was the firm, and each firm's ECSR investment was a function of firm-level factors. The level 1 's model is: ECSR $i, j=\beta_{0 j}+\beta_{1 j} X_{i j}+r_{i j}$. $i$ indexes each firm, $j$ indexes each province, $X_{\mathrm{ij}}$ is the vector of firm-level factors, including PB and other firm-level controls. $\beta_{0 \mathrm{j}}$ and $\beta_{1 \mathrm{j}}$ are, respectively, the intercept and slopes estimated for each province, and $\mathrm{r}_{\mathrm{ij}}$ is the residual. At level 2, the unit of analysis was the province, where the dependent variable was hypothesized to depend on specific province factors adjusted for the regression coefficients in the level 1 model. Thus, we used an intercept-as-outcome models instead of a slopes-as-outcome model. The level 2's model is: $\beta_{0 j}=\gamma_{00}+\gamma_{01} G_{j}+U_{0 j}$. where $\beta_{0 j}$ is the intercept from the level 1 equation above, $G_{j}$ is the provincial-level variable, $\gamma_{00}$ is the second level intercept terms and $\gamma_{01}$ is the slope relating the province-level-independent variable $\mathrm{G}$ to the intercept, and $\mathrm{U}_{0 \mathrm{j}}$ is the level 2 residual. Thus, to estimate the moderator effect of MarOrient using the HML model, we added the PB and its interaction term with MarOrient into level 1's model and added the MarOrient into level 2's model. This is because the interaction term between PB and MarOrient is actually a firm-level factor.

Specifically, we estimated the HML models by using the Stata commands "mixed" and "meprobit" (StataCorp 2013). A random-effects model, as opposed to a fixed-effect model, was used to deal with variance in our firm-level variables. This means, for the regressions that do not include the provincial-level independent variable, our HML models just include a random effect at the provincial level.

${ }^{8}$ We calculate the centered variance inflation factors (VIFs) after each of our regression model. The centered VIFs for all variables are no higher than 1.5 , indicating that our specification does not suffer multicollinearity. To save the space, the VIFs tables are available on request. 
[Insert Table 5 about here]

We subsequently test whether the relationship between Party branch (PB) and ECSR is affected by the central governance in private firms. In Table 5's columns (3) and (4), we add the CenGovern and the interaction term between Party branch (PB) and CenGovern into the model. The coefficients of Party branch (PB) are significantly positive, indicating that there is a positive correlation between Party branch (PB) and ECSR. Furthermore, the coefficients of the interaction term between Party branch (PB) and CenGovern are positively significant at a $5 \%$ level as well which shows that privately-owned firms with single decision-makers are prone to respond to their Party branch (PB) to pursue ECSR investment. In all, we find that the hypothesized moderating effects of CenGovern are statistically significant.

The interaction plots in Fig.2's Column (1) shows the moderator effect of the CenGovern. However, Holmbeck (2002) points out that "the presence of a significant interaction tells us that there is significant moderation, but tells us little about the specific conditions that dictate whether the predictor is significantly related to the outcome." So, we further conduct a post-hoc probing test by split our sample into two parts by the moderators. Results in Appendix Table 2's Panel A show that: 1) party branch setup significantly results in more ECSR for both types of firms with and without the central governance; 2) the effect of party branch setup on ECSR are more pronounced for subsample in which privatelyowned firms with the central governance. The above findings support our Hypothesis 2 that the positive association between CPC branch and ECSR is strengthened when there is central governance in the privately-owned firm. 
We further revise our specification to control Party branch, FC and the interaction term between them in Table 5's columns (5) and (6), and then we can test the moderating effect of FC. The coefficients of the interaction term between PB and FC are negatively significant at 10\% level in Model (5) and 5\% level at Model (6) respectively, indicating that firms' financial constraints impact its investment in ESCR. The interaction plot and post-hoc probing test also support the moderator effect of FC. These findings prove the statistical significance of the hypothesized moderating effects of FC, and support our Hypothesis 3 that the positive association between CPC branch and ECSR is weakened when the privatelyowned firm confronts financial constraint.

In Table 5's columns (7) and (8), we control Party branch, MarOrient and the interaction term between Party branch and MarOrient. Such specification is designed to test the moderating effect of MarOrient. Again, the coefficients of PB are significantly positive all the time, indicating that there is a robust positive correlation between CPC branch and ECSR. The coefficients of the interaction term between PB and MarOrient are positively significant at $10 \%$ level in Model (7) and 1\% level at Model (8) respectively, which shows that the adoption of CPC branch has a stronger effect on ECSR for firms located in regions with the better developed market system. The interaction plot and post-hoc probing test also support the empirical findings. So, the hypothesized moderating effects of market development are proved to be statistically significant. These findings support our Hypothesis 4 that the positive association between CPC branch and ECSR is strengthened when the private firm is located in regions with a higher level of market development. 


\section{Robustness check}

Table 5 shows the positive correlation between the existence of CPC branch and ECSR, but it may not be the causality, because the positive correlation may be caused by self-selection biases. For example, it is possible that firms with higher profitability, politically connected entrepreneurs or policy guided industries are more likely to set up CPC branch and invest in ECSR. If this is true, the observed positive correlation is caused by ex-ante selection. To rule out such concern, the propensity score matching (PSM) algorithm is utilized to construct the control sample following Rosenbaum and Rubin (1983), through which the ex-ante selection biased can be controlled as much as possible.

In model (1) of Table 6, privately-owned firms with CPC branch are matched with those without $\mathrm{CPC}$ branch on multiple dimensions of firm characteristics including firm size (Size_sales), age (Firm_age) and profitability (ROS). And we only use the matched privatelyowned firms without CPC branch for comparison. The panel for model (1) presents the comparison of means of ECSR investment (measured by EnInvest and LnEnInvest) for the firms with and without CPC branch before (unmatched) and after (ATT) the matching. It shows that the difference between firms with and without CPC branch in terms of CSR investment is still significantly positive after the matching, although the magnitudes of the differences drop after the matching. Similarly, as the robustness checks, in model (2) of Table 6, privately-owned firms with CPC branch are matched with those without CPC branch on entrepreneur characteristics (political connections (Party_member, PC, CPPCC, Prior_gov_job), gender (Gender), age (CEO_age), education (Edu_dummy)) besides firm characteristics, and in model (3) of Table 6, privately-owned firms with CPC branch are matched with those without CPC branch on firm characteristics, entrepreneur characteristics, industry and year. The findings remain unchanged. The estimates suggest that privately- 
owned firms with CPC branch outperform privately-owned firms without CPC branch in CSR investment after the potential ex-ante selection effects are controlled.

[Insert Table 6 about here]

Although PSM helps to cease the concern of ex-ante selection bias, the positive correlation may be caused by unobserved factors, such as privately-owned firms' culture. For example, if more socially responsible firms are more likely to set up CPC branch, the observed correlation is inflated by the unobservable variables. To solve the potential endogeneity problem, we use 2SLS with two instrument variables (IVs) to identify the effect of CPC branch. ${ }^{9}$

Following Guo et al. (2014), we use the existence of the labor union in a firm as the first IV. China's Labor Union Law was adopted in 2001, and the CPC encouraged every organization to set up a labor union including non-SOEs. But every unionized firm has to pay 2.5 percent of its payroll to support its union, so privately-owned firms have a little financial incentive to voluntarily set up the union. As unionization is encouraged by the CPC, we expect firms with CPC branches are more likely to have a union. However, the existence of the labor union in a firm alone should not be directly related to ECSR. Moreover, motivated by Hausman et al. (1994), we follow Du et al. (2015) to construct PB-Environ as the second IV. PB-Environ is the average ratio of privately-owned firms that already setup party branches in the survey year calculate by other surveyed firms in the same city.

\footnotetext{
${ }^{9}$ We conducted a Durbin-Wu-Hausman (DWH) Endogeneity tests. The p-value of the DWH test is 0.000, rejecting the null hypothesis that "the specified endogenous regressors can actually be treated as exogenous". This means that PB is an endogenous variable and the results in Table 5 maybe bias.
} 
Table 7 reports the two-stage least square model regressions for ECSR when the CPC branch is instrumented by Union and PB-Environ. The first stage regression result confirms that both instrumental variables Union and PB-Environ are significantly and positively correlated to $\mathrm{CPC}$ branch. The second stage regression results show that after the $\mathrm{CPC}$ branch is instrumented by Union and PB-Environ, the existence of CPC branch is still positively and significantly correlated with ECSR measured by all means, confirming the causality relationship between CPC branch and ECSR. Furthermore, Sargan tests (overidentification tests) fail to reject the null hypothesis that the instruments are exogenous, indicating the exogeneity of the two IVs. Wald tests (underidentification tests) reject the null hypothesis that our instruments are irrelevant. The two tests jointly show that our two IVs are relevant and exogeneous.

[Insert Table 7 about here]

In addition, as pointed by one of the referees, the positive correlation between ECSR investments and the existence of the PB may be due to government policy, especially when China starts to emphasize more and more the importance of environment protection. Actually, the Chinese government started to implement the Two Control Zones (TCZ) policy since 1998. ${ }^{10}$ Tougher environmental regulations were imposed on firms located in these zones. So, firms in our sample which are located in TCZ are more likely to be influenced by government policy. In other words, their total investments are more likely to be affected by government policy rather than voluntary incentives. We divide our sample into two samples, firms located in TCZ and others not in TCZ. If the assumption that the environmental investment is purely

\footnotetext{
${ }^{10} \mathrm{http} / / /$ www.gov.cn/zhengce/content/2010-11/22/content_5181.htm
} 
driven by government policy is right, the coefficient of PB for firms located outside the TCZ should be insignificant. The results are shown in Table 8 . The estimated coefficients of PB for firms located outside TCZ are significant from Model (3) to (4). This subsample analysis shows that after controlling the effect of government policy, firms with party branches have more ECSR.

[Insert Table 8 about here]

\section{Discussion and conclusion}

Our study is centrally interested in the endeavour to explain how political connections motivate firms ECSR investments for a more environmentally sustainable future. Motivated by the reciprocal logic, an entrepreneur who benefited from adopting a CPC branch is likely to try to score with the CPC and thus to invest in ECSR (Cropanzano and Mitchell 2005; Cropanzano et al. 2017; Emerson 1976). One the one hand, they can eliminate the pressure originated from the reciprocity, help the goals of the Party, and gain credit for potential intrinsic motivations. On the other hand, they can gain potential positive feedback from the $\mathrm{CPC}$ in the future in the form of access to resources or the involvement in the consultation processes for new legislation that is relevant to their business.

We examine these ideas based on data analyses of a sample of 17,690 privately-owned firms in China and find that privately-owned firms with CPC branches are indeed more likely to undertake non-obligatory ECSR investments. This association is more pronounced when entrepreneurs are the final decision-makers in their firms and when firms are located in 
regions with higher levels of market-orientation. The link is weakened when entrepreneurs face financial constraints. However, in all cases, the size of the investment is fairly small.

\section{Theoretical implications}

Our study contributes to the literature in three ways. First, we identify an organizational level political connection (i.e., adoption of the CPC branch) and connect it to non-obligatory investments. Interestingly, the system of CPC branches is based on removing the idea of direct reciprocity between people to potential long-term benefits that are - while culturally embedded - vague in its extent, institutionalized on the organizational level, and unspecific regarding the temporal sphere. Filling the gap between charitable giving and fulfilling legal obligations is an important step to open up a space that is potentially neither entirely humanistic in its motivation, nor entirely economically motivated. Instead, there may be a dual sphere in which both motivations exist. From our setting, we also learn that a third motivational factor such as personal belief may be considered to be influential for voluntary investment decisions as well as potential reciprocal actions. Our analysis, however, shows that non-obligatory ECSR investments are very small if they exist and we cannot exclude that they occur under opportunistic motives.

Second, we provide empirical evidence for our contingency model on non-obligatory ECSR investments. CPC branches are a clear signal to the CPC that the private firm wants to engage with CPC directives. We identify three important factors that contribute or restrain ECSR investment in firms that chose to build a CPC branch. One, privately-owned firms under the majority or sole ownerships of the entrepreneur are more likely to contribute to ECSR. This result adds some clarification to prior research that has found mixed results, but has been undertaken in other or with less distinct ownership categories. Our setting reduces the extent of goal conflicts within the firm (Cyert and March 1963) in comparison to prior 
work and shows that while economic reasons are likely to prevalent in most cases, there may be firm and individual level considerations that lead to non-obligatory ECSR investments. In addition, our starting was that an entrepreneur with the choice to install or not install a CPC branch does this to establish clear linkages that should indicate that they are willing to follow the CPC's directives and that they recognize that they follow the leadership of the CPC. We find that in some cases, the installation of a CPC branch in itself may be the desired signal and we find very restrictive non-obligatory investment patterns.

Similarly, privately-owned firms invest more in fulfilling CPC directives if they have some financial slack to do so. This finding is consistent with the literature on financial slack and ECSR. Firms contribute if they can afford to invest in a shared goal. If firms face financial constraints, voluntary contributions to a public cause reduce the ability to give.

Firms operating in areas with higher levels of marketization are relatively bigger investors into ECSR. This finding confirms our explanation that expected reciprocity from the CPC/government and the competitions among peer firms may drive privately-owned firms to work more closely along the lines directed by the CPC by making more ECSR investments.

Third, our study contributes to the social exchange theory by applying it to a unique setting. The social exchange theory explains exchanges and how they happen, explicating relationships formed on the basis of social exchanges (Cropanzano and Mitchell 2005; Emerson 1976). Despite the calls for studies beyond exchanges between two people (Cropanzano et al. 2017), most research has discussed individual exchanges rather than exchanges between individuals and organizational entities. In this paper, however, we approach the exchanges between individuals (i.e., entrepreneurs) and organizational entities (i.e., CPC branches in private firms), thus answering the calls from Cropanzano et al. (2017). 
Actually, the strength of our study is the focus on entrepreneurs who own (by majority share) their firms and thus are able to interact with the CPC branches in their firms. Such a setting offers us a great opportunity to approach the social exchange theory in a unique way and extend its applications. Moreover, most research using the social exchange theory has focused on economic exchanges. In our setting, however, we find that other forms such as information, power or philanthropy may also play a role.

This paper is not without limitations. Most interestingly, while we confirm our hypothesis, the absolute and also relative contributions, the investments by privately-owned firms are very small. In fact, in most cases, the non-obligatory investments are not substantial and at best provide a signalling effect that a contribution was made. However, the size of the contributions is so limited that they are unlikely to make a difference in achieving environmental goals set by the CPC. Additionally, while we discuss much about ECSR, we acknowledge that there may be an ethical dimension concerning such investments. The scope and space limitations of this paper made it necessary to reduce this discussion to a minimum.

\section{Managerial Implications}

This paper has interesting managerial implications. First, entrepreneurs in Chinese privately-owned firms need to know that in addition to their personal ties to government officials, installation of a CPC branch could also serve the role of political connections. Similar to the former, the latter could also benefit entrepreneurs' firms in multiple ways such as gaining crucial information and opportunities from the government and securing resources that are not available in the market. More importantly, the CPC branches strive to contribute to the development of privately-owned firms in a proactive way by offering advice as well as by assisting in human resources management. As a result, the CPC branches in privatelyowned firms become a personalized entity that interacts with the entrepreneurs, which could 
not be realized by simply establishing personal ties with the government officials. Entrepreneurs really need to gain a better understanding of this unique type of political connection in the Chinese setting.

Second, entrepreneurs may understand their voluntary ECSR engagement more fully by comprehending the social exchange logic that this paper is built on. As we have mentioned, the CPC branches act as a personalized entity that tries all out to help entrepreneurs and their firms. Although their primary goal is to gain a foothold in the privately-owned firms so as to fulfill their roles as grass-root organizations of the $\mathrm{CPC}$, their existence is actually conducive to the development of privately-owned firms. To reciprocate, and also to gain future rewards, entrepreneurs echo the call from the CPC and contribute to the ECSR investment (Cropanzano and Mitchell 2005; Emerson 1976).

Third, based on the findings of this paper, entrepreneurs may also gain a deeper understanding of how their willingness to do good to the environment may be suppressed by the corporate governance, financial conditions and the task environment in which they embedded. Although the regional environment is beyond the control of entrepreneurs, they may strive to alter the intra-firm environment so as to interact with the CPC branch and the $\mathrm{CPC}$ in a more intimate way.

\section{Compliance with Ethical Standards}

Ethical approval: This article does not contain any studies with human participants or animals performed by any of the authors.

Conflict of Interest: Each author declares that he/she has no conflict of interest. 


\section{References}

Aiken, L. S., West, S. G., \& Reno, R. R. (1991). Multiple regression: Testing and interpreting interactions. London: Sage Publications.

Arnoldi, J., \& Muratova, Y. (2019). Unrelated acquisitions in China: The role of political ownership and political connections. Asia Pacific Journal of Management, 36(1), 113-134.

Ang Y Y, Jia N. (2014). Perverse complementarity: Political connections and the use of courts among private firms in China. Journal of Politics, 76(2): 318-332.

Babiak, K., \& Trendafilova, S. (2011). CSR and environmental responsibility: motives and pressures to adopt green management practices. Corporate Social Responsibility and Environmental Management, 18(1), 11-24.

Biswas, U. A., Garg, S., \& Singh, A. (2016). Government intervention and corporate social responsibility in India. International Journal of Indian Culture and Business Management, 13(4), 450-473.

Blau, P.M. (1964). Exchange and power in social life. New York: John Wiley \& Sons.

Campello, M., Graham, J. R., \& Harvey, C. R. (2010). The real effects of financial constraints: Evidence from a financial crisis. Journal of Financial Economics, 97(3), 470-487.

Carroll, A. B. (1991). The pyramid of corporate social responsibility: Toward the moral management of organizational stakeholders. Business Horizons, 34(4), 39-48.

Carroll, A. B. (1999). Corporate social responsibility: Evolution of a definitional construct. Business \& Society, 38(3), 268-295.

Chang, Y. K., Oh, W. Y., Park, J. H., \& Jang, M. G. (2017). Exploring the relationship between board characteristics and CSR: Empirical evidence from Korea. Journal of Business Ethics, 140(2), 225-242.

Cheung, Y. L., Jiang, K., \& Tan, W. (2012). 'Doing-good' and 'doing-well' in Chinese publicly listed firms. China Economic Review, 23(4), 776-785. 
Cropanzano, R., Anthony, E. L., Daniels, S. R., \& Hall, A. V. (2017). Social exchange theory: A critical review with theoretical remedies. Academy of Management Annals, 11(1), 479-516.

Cropanzano, R., \& Mitchell, M. S. (2005). Social exchange theory: An interdisciplinary review. Journal of Management, 31(6), 874-900.

Cumming, D., Hou, W., \& Lee, E. (2016). Business ethics and finance in greater China: Synthesis and future directions in sustainability, CSR, and fraud. Journal of Business Ethics, 138(4), 601-626.

Cyert, R. M., \& March, J. G. (1963). A behavioral theory of the firm, 2nd ed. Englewood Cliffs: Prentice Hall.

Dahlsrud, A. (2008). How corporate social responsibility is defined: An analysis of 37 definitions. Corporate Social Responsibility and Environmental Management, 15(1), 1-13.

Dai, W., \& Liao, M. (2019). Entrepreneurial attention to deregulations and reinvestments by private firms: Evidence from China. Asia Pacific Journal of Management, 36(4), 1221-1250.

Darigan, K. H., \& Post, J. E. (2009). Corporate citizenship in China: CSR challenges in the 'Harmonious Society'. Journal of Corporate Citizenship, (35), 39-53.

Dong, Z., Luo, Z., \& Wei, X. (2016). Social insurance with Chinese characteristics: The role of communist party in private firms. China Economic Review, 37, 40-51.

Du, J., Lu, Y., \& Tao, Z. (2015). Government expropriation and Chinese-style firm diversification. Journal of Comparative Economics, 43(1), 155-169.

Emerson, R. M. (1976). Social exchange theory. Annual Review of Sociology, 2(1), 335-362.

Faccio, M., Masulis, R. W., \& McConnell, J. J. (2006). Political connections and corporate bailouts. The Journal of Finance, 61(6), 2597-2635.

Fazzari, S., Hubbard, R. G., \& Petersen, B. C. (1988). Financing constraints and corporate investment. Brookings Papers on Economic Activity, 19(1): 141-195. 
Fischer, E., \& Reuber, A. R. (2010). Support for rapid-growth firms: A comparison of the views of founders, government policymakers, and private sector resource providers. Journal of Small Business Management, 41(4), 346-365.

Flammer, C. (2013). Corporate social responsibility and shareholder reaction: The environmental awareness of investors. Academy of Management Journal, 56(3), 758-781.

Frynas, J. G., \& Stephens, S. (2015). Political corporate social responsibility: Reviewing theories and setting new agendas. International Journal of Management Reviews, 17(4), 483-509.

G Gao, Y., \& Hafsi, T. (2015). Government intervention, peers' giving and corporate philanthropy: Evidence from Chinese private SMEs. Journal of Business Ethics, 132(2), 433-447.

Gamerschlag, R., \& Verbeeten, F. (2011). Determinants of voluntary CSR disclosure: Empirical evidence from Germany. Review of Managerial Science, 5(2-3), 233-262.

Goll, I., and Rasheed, A. A. (2004). The moderating effect of environmental munificence and dynamism on the relationship between discretionary social responsibility and firm performance. Journal of Business Ethics, 49(1), 41-54.

González, M. D. L. C., \& Martinez, C. V. (2004). Fostering corporate social responsibility through public initiative: From the EU to the Spanish case. Journal of Business Ethics, 55(3), 275-293.

Guo, D., Jiang, K., Kim, B. Y., \& Xu, C. (2014). Political economy of private firms in China. Journal of Comparative Economics, 42(2), 286-303.

Graham, J. R., Harvey, C. R., \& Rajgopal, S. (2004). The economic implications of corporate financial reporting. Journal of Accounting \& Economics, 40(1), 3-73.

Hadlock, C. J., \& Pierce, J. R. (2010). New evidence on measuring financial constraints: Moving beyond the KZ index. The Review of Financial Studies, 23(5), 1909-1940.

Hausman, J., Leonard, G., \& Zona, J. D. (1994). Competitive analysis with differenciated products. Annales D'Economie et de Statistique, 34, 159-180. 
He, Q., Li, X., \& Zhu, W. (2018). Political connection and the walking dead: Evidence from China's privately owned firms. International Review of Economics \& Finance. doi: 10.1016/j.iref.2018.12.007

Heckathorn, D. D. (1993). Collective action and group heterogeneity: Voluntary provision versus selective incentives. American Sociological Review, 58(3), 329-350.

Hofmann, D. A. (1997). An overview of the logic and rationale of hierarchical linear models. Journal of Management, 23(6), 723-744.

Holmbeck, G. N. (2002). Post-hoc probing of significant moderational and mediational effects in studies of pediatric populations. Journal of Pediatric Psychology, 27(1), 87-96.

Jia, N. (2014). Are collective political actions and private political actions substitutes or complements? Empirical evidence from China's private sector. Strategic Management Journal, 35(2), 292-315.

Julian, S. D., \& Ofori-dankwa, J. C. (2013). Financial resource availability and corporate social responsibility expenditures in a sub-Saharan economy: The institutional difference hypothesis. Strategic Management Journal, 34(11), 1314-1330.

Kafouros, M., \& Aliyev, M. (2016). Institutions and foreign subsidiary growth in transition economies: The role of intangible assets and capabilities. Journal of Management Studies, 53(4), 580-607.

Katmon, N., \& Al Farooque, O. (2017). Exploring the impact of internal corporate governance on the relation between disclosure quality and earnings management in the UK listed companies. Journal of Business Ethics, 142(2), 345-367.

Lepoutre, J., \& Heene, A. (2006). Investigating the impact of firm size on small business social responsibility: A critical review. Journal of Business Ethics, 67(3), 257-273.

Li, H., Meng, L., Wang, Q., \& Zhou, L. A. (2008). Political connections, financing and firm performance: Evidence from Chinese private firms. Journal of Development Economics, 87(2), 283-299.

Li, S., Song, X., \& Wu, H. (2015). Political connection, ownership structure, and corporate philanthropy in China: A strategic-political perspective. Journal of Business Ethics, 129(2), 399-411. 
Li, W., \& Zhang, R. (2010). Corporate social responsibility, ownership structure, and political interference: Evidence from China. Journal of Business Ethics, 96(4), 631-645.

Lin, K. J., Tan, J., Zhao, L., \& Karim, K. (2015). In the name of charity: Political connections and strategic corporate social responsibility in a transition economy. Journal of Corporate Finance, 32, 327-346.

Zhao, H., \& Lu, J. (2016). Contingent value of political capital in bank loan acquisition: Evidence from founder-controlled private enterprises in China. Journal of Business Venturing, 31(2), 153-174.

Luo, J. H., Huang, Z., Li, X., \& Lin, X. (2018). Are women CEOs valuable in terms of bank loan costs? Evidence from China. Journal of Business Ethics, 153(2), 337-355.

Matten, D., \& Moon, J. (2008). "Implicit" and "explicit" CSR: A conceptual framework for a comparative understanding of corporate social responsibility. Academy of management Review, 33(2), 404-424.

Muttakin, M. B., Mihret, D. G., \& Khan, A. (2018). Corporate political connection and corporate social responsibility disclosures. Accounting Auditing \& Accountability Journal, 31(2), 725-744.

Peng, M. W., \& Luo, Y. (2000). Managerial ties and firm performance in a transition economy: The nature of a micro-macro link. Academy of Management Journal, 43(3), 486-501.

Pfeffer, J., \& Salancik, G. R. (1978). The External Control of Organizations: A Resource Dependence Perspective. New York: Harper and Row.

Rosenbaum, P. R., \& Rubin, D. B. (1983). Assessing sensitivity to an unobserved binary covariate in an observational study with binary outcome. Journal of the Royal Statistical Society, 45(2), 212-218.

Scherer, A. G., \& Palazzo, G. (2007). Toward a political conception of corporate responsibility: Business and society seen from a Habermasian perspective. Academy of Management Review, 32(4), 1096-1120.

Scherer, A. G., Palazzo, G., \& Matten, D. (2014). The business firm as a political actor: A new theory of the firm for a globalized world. Business \& Society, 53(2), 143-156.

Scott, T. W. (1994). Incentives and disincentives for financial disclosure: Voluntary disclosure of defined benefit pension plan information by Canadian firms. Accounting Review, 69(1), 26-43. 
Shi, X., \& Xu, Z. (2018). Environmental regulation and firm exports: Evidence from the eleventh FiveYear Plan in China. Journal of Environmental Economics and Management, 89, 187-200.

Shum, P. K. (2011). Ethics and law: guiding the invisible hand to correct corporate social responsibility externalities. Journal of Business Ethics, 98(4), 549-571.

StataCorp, L. P. (2013). Stata multilevel mixed-effects reference manual. College Station, TX: StataCorp $L P, 9,10$.

Sun, S. L., Yang, X., \& Li, W. (2014). Variance-enhancing corporate entrepreneurship under deregulation: an option portfolio approach. Asia Pacific Journal of Management, 31(3), 733-761.

Sun, P., \& Wright, M. (2012). The contingent value of corporate political ties. Academy of Management Perspectives, 26(3), 68-82.

Tang, Z., \& Tang, J. (2012). Stakeholder-firm power difference, stakeholders' CSR orientation, and SMEs' environmental performance in China. Journal of Business Venturing, 27(4), 436-455.

Tihanyi, L., Aguilera, R. V., Heugens, P., van Essen, M., Sauerwald, S., Duran, P., \& Turturea, R. (2019). State ownership and political connections. Journal of Management, 45(6), 2293-2321.

Wei, Z., Shen, H., Zhou, K. Z., \& Li, J. J. (2017). How does environmental corporate social responsibility matter in a dysfunctional institutional environment? Evidence from China. Journal of Business Ethics, 140(2), 209-223.

Xing, Y., Liu, Y., \& Cooper, S. C. L. (2018). Local government as institutional entrepreneur: Publicprivate collaborative partnerships in fostering regional entrepreneurship. British Journal of Management, 29(4), 670-690.

$\mathrm{Xu}, \mathrm{Y}$. (2011). The use of a goal for SO2 mitigation planning and management in China's 11th Five-Year Plan. Journal of Environmental Planning and Management, 54(6), 769-783.

Yuan, Y., \& Min, T. (2018). Finding the ethics of "red capitalists": Political connection and philanthropy of Chinese private entrepreneurs. Journal of Business Ethics. doi: 10.1007/s10551-018-3934-y. 
Zhang, Y., \& Epley, N. (2009). Self-centered social exchange: Differential use of costs versus benefits in prosocial reciprocity. Journal of Personality and Social Psychology, 97(5), 796.

Zhao, M. (2012). CSR-based political legitimacy strategy: Managing the state by doing good in China and Russia. Journal of Business Ethics, 111(4), 439-460.

Zhao, H., \& Lu, J. (2016). Contingent value of political capital in bank loan acquisition: Evidence from founder-controlled private enterprises in China. Journal of Business Venturing, 31(2), 153-174.

Zhou, K. Z., \& Poppo, L. (2010). Exchange hazards, relational reliability, and contracts in China: The contingent role of legal enforceability. Journal of International Business Studies, 41(5), 861-881. 


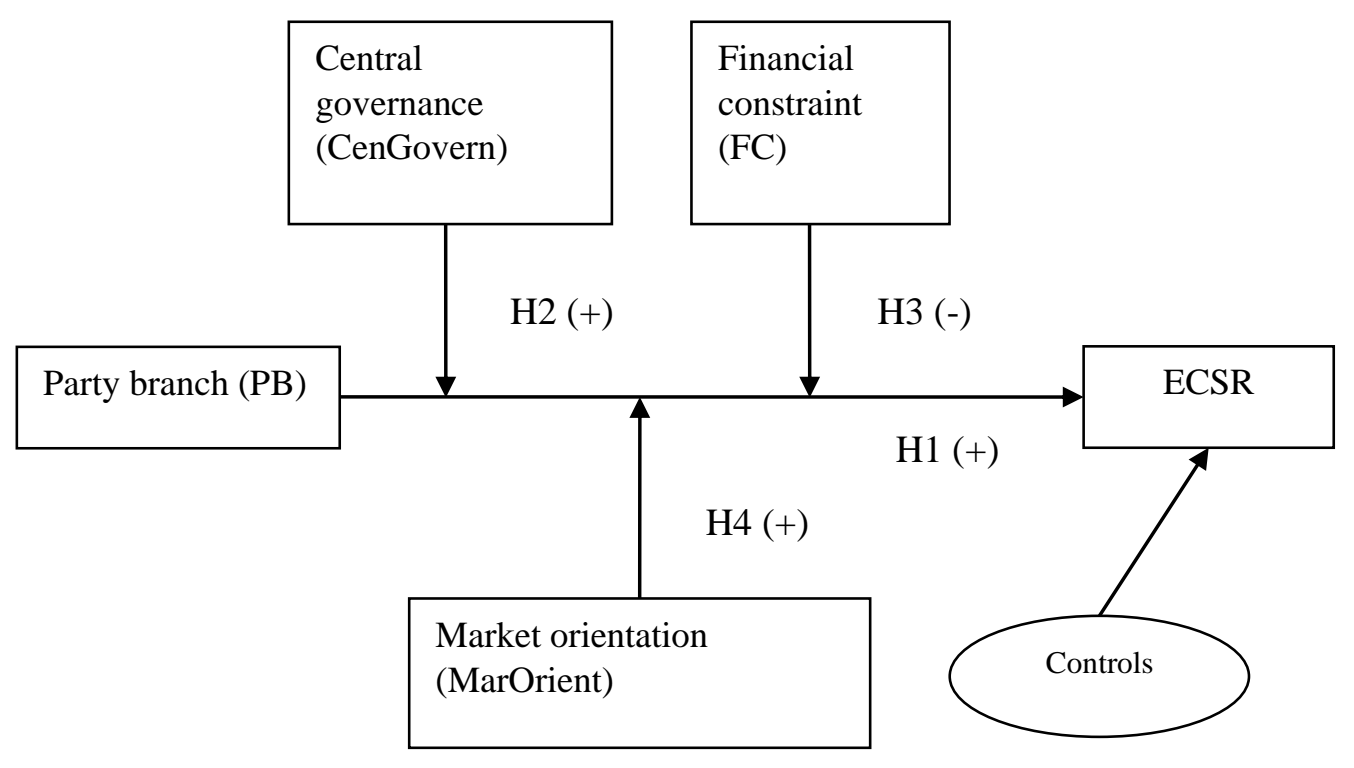

Fig. 1. The theoretical model 

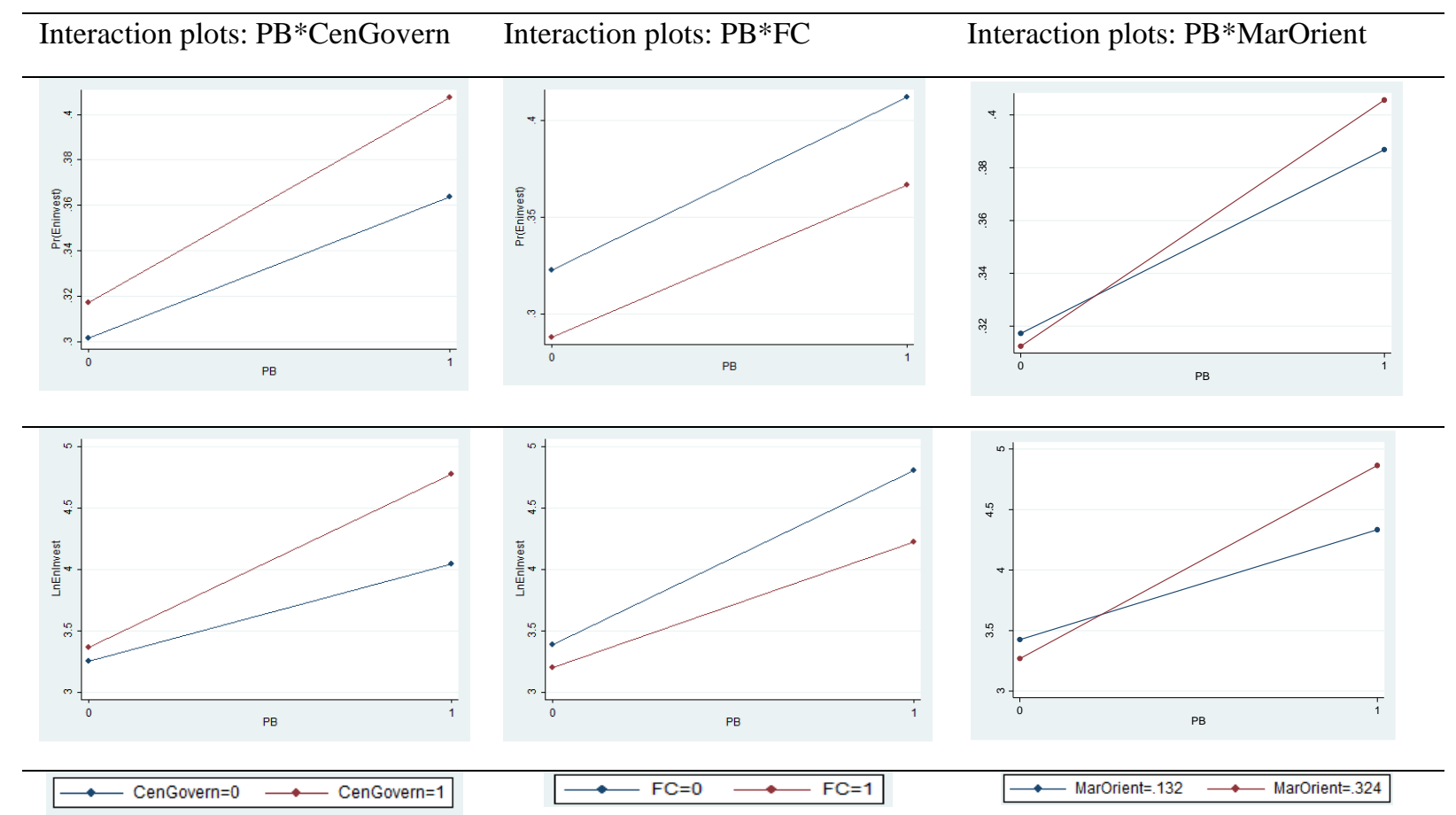

Fig. 2. The interaction plots

As the MarOrient is a continuous variable, following Aiken and West (1991), we chose two point 0.132 (one standard deviation below the mean) and 0.324 (one standard deviation above the mean) when drawing the interaction plots. The $\mathrm{X}$ axis is the independent variable PB. The $\mathrm{Y}$ axis is the predictor of the dependent variable ECSR. 
Table 1 Sample distribution

\begin{tabular}{|c|c|c|c|c|c|c|c|c|c|}
\hline \multicolumn{10}{|c|}{ Panel A: by province } \\
\hline Province & Sample & $\begin{array}{c}\text { Perc } \\
\text { ent }\end{array}$ & Province & Sample & Percent & \multicolumn{2}{|c|}{ it Province } & Sample & Percent \\
\hline Anhui & 485 & $3 \%$ & Hubei & 875 & $5 \%$ & \multicolumn{2}{|c|}{ Shaanxi } & 363 & $2 \%$ \\
\hline Beijing & 753 & $4 \%$ & Hunan & 431 & $2 \%$ & \multicolumn{2}{|c|}{ Shanghai } & 1,208 & $7 \%$ \\
\hline Fujian & 338 & $2 \%$ & Jilin & 474 & $3 \%$ & \multicolumn{2}{|c|}{ Sicuan } & 602 & $3 \%$ \\
\hline Gansu & 304 & $2 \%$ & Jiangsu & 1,925 & $11 \%$ & \multicolumn{2}{|c|}{ Tianjin } & 392 & $2 \%$ \\
\hline Guangdong & 1,303 & $7 \%$ & Jiangxi & 386 & $2 \%$ & \multicolumn{2}{|c|}{ Tibet } & 40 & $0 \%$ \\
\hline Guangxi & 316 & $2 \%$ & Liaoning & 775 & $4 \%$ & \multicolumn{2}{|c|}{ Xinjiang } & 188 & $1 \%$ \\
\hline Guizhou & 340 & $2 \%$ & Inner Mongolia & 290 & $2 \%$ & \multicolumn{2}{|c|}{ Yunnan } & 258 & $1 \%$ \\
\hline Hainan & 245 & $1 \%$ & Ningxia & 203 & $1 \%$ & \multicolumn{2}{|c|}{ Zhejiang } & 1,352 & $8 \%$ \\
\hline Hebei & 586 & $3 \%$ & Qinghai & 154 & $1 \%$ & \multirow{3}{*}{\multicolumn{2}{|c|}{ Chongqing }} & 625 & $4 \%$ \\
\hline Henan & 503 & $3 \%$ & Shandong & 1,133 & $6 \%$ & & & & \\
\hline Heilongjiang & 505 & $3 \%$ & Shanxi & 338 & $2 \%$ & & & & \\
\hline \multicolumn{10}{|c|}{ Panel B: by industries } \\
\hline \multicolumn{4}{|l|}{ Industry } & 2006 & 2008 & 2010 & 2012 & 2014 & Total \\
\hline \multicolumn{4}{|c|}{ Agriculture, forestry, animal husbandry and fishing } & 149 & 188 & 281 & 268 & 373 & 1,259 \\
\hline \multicolumn{4}{|c|}{ Mining } & 42 & 55 & 100 & 74 & 70 & 341 \\
\hline \multicolumn{4}{|l|}{ Manufacturing } & 1,108 & 1,218 & 1,355 & 1,508 & 1,599 & 6,788 \\
\hline \multicolumn{4}{|c|}{ Electric power, heat, gas and water production } & 30 & 28 & 38 & 34 & 52 & 182 \\
\hline \multicolumn{4}{|l|}{ Construction } & 122 & 143 & 226 & 273 & 288 & 1,052 \\
\hline \multicolumn{4}{|c|}{ Transportation and storage } & 63 & 61 & 109 & 122 & 107 & 462 \\
\hline \multicolumn{4}{|c|}{ Information technology } & 88 & 144 & 174 & 151 & 157 & 714 \\
\hline \multicolumn{4}{|c|}{ Wholesale and retail } & 483 & 498 & 606 & 676 & 754 & 3,017 \\
\hline \multicolumn{4}{|c|}{ Hotels and catering services } & 105 & 112 & 142 & 157 & 185 & 701 \\
\hline \multicolumn{4}{|l|}{ Real estate } & 54 & 65 & 89 & 97 & 132 & 437 \\
\hline \multicolumn{4}{|c|}{ Rental and commercial service } & 19 & 25 & 35 & 117 & 182 & 378 \\
\hline \multicolumn{4}{|c|}{ Personal care $\&$ services } & 50 & 59 & 76 & 38 & 147 & 370 \\
\hline \multicolumn{4}{|c|}{ Science, education, culture and public health } & 73 & 75 & 98 & 91 & 187 & 524 \\
\hline \multicolumn{4}{|l|}{ Others } & 193 & 432 & 107 & 321 & 412 & 1,465 \\
\hline \multicolumn{4}{|l|}{ Total } & 2,579 & 3,103 & 3,436 & 3,927 & 4,645 & 17,690 \\
\hline
\end{tabular}


Table 2 Summary statistics

\begin{tabular}{lcccccccc}
\hline variable & Mean & SD & Min & P5 & P25 & P50 & P75 & P95 \\
\hline EnInvest & 0.345 & 0.475 & 0 & 0 & 0 & 0 & 1 & 1 \\
LnEnInvest & 3.768 & 5.405 & 0 & 0 & 0 & 0 & 9.904 & 13.430 \\
PB & 0.331 & 0.470 & 0 & 0 & 0 & 0 & 1 & 1 \\
CenGovern & 0.750 & 0.433 & 0 & 0 & 1 & 1 & 1 & 1 \\
MarOrient & 0.228 & 0.096 & 0.034 & 0.077 & 0.157 & 0.219 & 0.300 & 0.391 \\
FC & 0.282 & 0.450 & 0 & 0 & 0 & 0 & 1 & 1 \\
Party_member & 0.358 & 0.479 & 0 & 0 & 0 & 0 & 1 & 1 \\
PC & 0.241 & 0.427 & 0 & 0 & 0 & 0 & 0 & 1 \\
CPPCC & 0.304 & 0.460 & 0 & 0 & 0 & 0 & 1 & 1 \\
Prior_gov_job & 0.166 & 0.372 & 0 & 0 & 0 & 0 & 0 & 1 \\
Gender & 0.147 & 0.354 & 0 & 0 & 0 & 0 & 0 & 1 \\
CEO_age & 3.808 & 0.192 & 3.219 & 3.466 & 3.689 & 3.829 & 3.951 & 4.094 \\
Edu_dummy & 0.570 & 0.495 & 0 & 0 & 0 & 1 & 1 & 1 \\
Size_sales & 16.008 & 2.307 & 9.903 & 12.051 & 14.403 & 16.118 & 17.707 & 19.683 \\
Firm_age & 2.087 & 0.686 & 0 & 0.693 & 1.792 & 2.197 & 2.565 & 2.996 \\
ROS & 0.096 & 0.203 & -0.980 & -0.045 & 0.011 & 0.048 & 0.125 & 0.500 \\
\hline
\end{tabular}


Table 3 Correlation matrix

\begin{tabular}{|c|c|c|c|c|c|c|c|c|c|c|c|c|c|c|c|c|c|}
\hline & EnInvest & (1) & (2) & (3) & (4) & (5) & (6) & (7) & (8) & (9) & (10) & (11) & (12) & (13) & (14) & (15) & (16) \\
\hline 1.LnEnInvest & 0.96 & & & & & & & & & & & & & & & & \\
\hline 2.PB & 0.27 & 0.30 & & & & & & & & & & & & & & & \\
\hline 3.CenGovern & 0.08 & 0.09 & 0.15 & & & & & & & & & & & & & & \\
\hline 4.MarOrient & 0.06 & 0.08 & 0.05 & -0.02 & & & & & & & & & & & & & \\
\hline 5.FC & -0.06 & -0.07 & -0.03 & -0.01 & -0.03 & & & & & & & & & & & & \\
\hline 6.Party_member & 0.12 & 0.13 & 0.33 & 0.07 & 0.07 & -0.01 & & & & & & & & & & & \\
\hline 7.PC & 0.19 & 0.21 & 0.30 & 0.09 & 0.03 & 0.04 & 0.18 & & & & & & & & & & \\
\hline 8.CPPCC & 0.14 & 0.15 & 0.21 & 0.08 & -0.02 & 0.02 & 0.03 & 0.32 & & & & & & & & & \\
\hline 9.Prior_gov_job & 0.09 & 0.10 & 0.21 & 0.10 & 0.01 & -0.02 & 0.25 & 0.11 & 0.05 & & & & & & & & \\
\hline 10.Gender & -0.09 & -0.09 & -0.11 & -0.06 & -0.02 & 0.01 & -0.11 & -0.07 & -0.06 & -0.09 & & & & & & & \\
\hline 11.CEO_age & 0.11 & 0.12 & 0.19 & 0.05 & 0.02 & 0.00 & 0.21 & 0.16 & 0.11 & 0.24 & -0.10 & & & & & & \\
\hline 12.Edu_dummy & 0.03 & 0.04 & 0.11 & 0.04 & 0.03 & -0.02 & 0.07 & 0.07 & 0.06 & 0.05 & 0.01 & -0.07 & & & & & \\
\hline 13.Size_sales & 0.33 & 0.38 & 0.48 & 0.18 & 0.12 & -0.07 & 0.20 & 0.32 & 0.26 & 0.18 & -0.14 & 0.22 & 0.15 & & & & \\
\hline 14.Firm_age & 0.12 & 0.14 & 0.19 & 0.06 & 0.02 & -0.06 & 0.08 & 0.14 & 0.17 & 0.09 & -0.07 & 0.29 & 0.04 & 0.30 & & & \\
\hline 15.ROS & 0.00 & -0.01 & -0.08 & -0.04 & -0.01 & -0.13 & -0.03 & -0.01 & -0.01 & -0.05 & 0.02 & -0.06 & -0.02 & -0.19 & -0.03 & & \\
\hline 16. Union & 0.27 & 0.29 & 0.57 & 0.16 & 0.04 & 0.00 & 0.20 & 0.27 & 0.23 & 0.18 & -0.09 & 0.20 & 0.10 & 0.48 & 0.23 & -0.10 & \\
\hline 17. PO_Enviro & 0.17 & 0.20 & 0.40 & 0.11 & 0.12 & -0.02 & 0.15 & 0.20 & 0.17 & 0.12 & -0.07 & 0.13 & 0.07 & 0.36 & 0.18 & -0.07 & 0.34 \\
\hline
\end{tabular}


Table 4 Comparison table

\begin{tabular}{|c|c|c|c|c|c|}
\hline \multirow{2}{*}{ Variables } & \multicolumn{2}{|c|}{$\mathrm{G} 1: \mathrm{PB}=0$} & \multicolumn{2}{|c|}{$\mathrm{G} 2: \mathrm{PB}=1$} & \multirow{2}{*}{ MeanDiff } \\
\hline & $\mathrm{N}$ & Mean & $\mathrm{N}$ & Mean & \\
\hline EnInvest & 11843 & 0.256 & 5847 & 0.527 & $-0.271 * * *$ \\
\hline LnEnInvest & 11843 & 2.621 & 5847 & 6.09 & $-3.469 * * *$ \\
\hline Party_member & 11843 & 0.248 & 5847 & 0.582 & $-0.334 * * *$ \\
\hline $\mathrm{PC}$ & 11843 & 0.149 & 5847 & 0.425 & $-0.276^{* * *}$ \\
\hline СРPCC & 11843 & 0.237 & 5847 & 0.44 & $-0.203 * * *$ \\
\hline Prior_gov_job & 11843 & 0.11 & 5847 & 0.278 & $-0.167 * * *$ \\
\hline Gender & 11843 & 0.173 & 5847 & 0.094 & $0.079 * * *$ \\
\hline CEO_age & 11843 & 3.781 & 5847 & 3.86 & $-0.079 * * *$ \\
\hline Edu_dummy & 11843 & 0.531 & 5847 & 0.647 & $-0.116 * * *$ \\
\hline Size_sales & 11843 & 15.227 & 5847 & 17.589 & $-2.361 * * *$ \\
\hline Firm_age & 11843 & 1.993 & 5847 & 2.276 & $-0.283 * * *$ \\
\hline ROS & 11843 & 0.108 & 5847 & 0.071 & $0.036^{* * *}$ \\
\hline
\end{tabular}


Table 5 The Party branch and ECSR

\begin{tabular}{|c|c|c|c|c|c|c|c|c|}
\hline & $\begin{array}{c}(1) \\
\text { EnInvest } \\
\end{array}$ & $\begin{array}{c}\text { (2) } \\
\text { LnEnInvest } \\
\end{array}$ & $\begin{array}{c}(3) \\
\text { EnInvest } \\
\end{array}$ & $\begin{array}{c}(4) \\
\text { LnEnInvest } \\
\end{array}$ & $\begin{array}{c}(5) \\
\text { EnInvest } \\
\end{array}$ & $\begin{array}{c}(6) \\
\text { LnEnInvest } \\
\end{array}$ & $\begin{array}{c}(7) \\
\text { EnInvest } \\
\end{array}$ & $\begin{array}{c}(8) \\
\text { LnEnInvest } \\
\end{array}$ \\
\hline $\mathrm{PB}$ & $\begin{array}{l}0.105^{* * *} \\
(11.283)\end{array}$ & $\begin{array}{l}1.306^{* * *} \\
(11.342)\end{array}$ & $\begin{array}{l}0.070^{* * *} \\
(3.663)\end{array}$ & $\begin{array}{c}0.786^{* * *} \\
(3.465)\end{array}$ & $\begin{array}{l}0.111^{* * * *} \\
(10.208)\end{array}$ & $\begin{array}{l}1.416^{* * *} \\
(10.880)\end{array}$ & $\begin{array}{l}0.063^{*} \\
(2.370)\end{array}$ & $\begin{array}{c}0.473 \\
(1.436)\end{array}$ \\
\hline CenGovern & & & $\begin{array}{l}0.011^{+} \\
(1.652)\end{array}$ & $\begin{array}{c}0.114 \\
(1.630)\end{array}$ & & & & \\
\hline PB*CenGovern & & & $\begin{array}{l}0.041^{*} \\
(2.097)\end{array}$ & $\begin{array}{l}0.619^{*} \\
(2.576)\end{array}$ & & & & \\
\hline $\mathrm{FC}$ & & & & & $\begin{array}{l}-0.026^{*} \\
(-2.390)\end{array}$ & $\begin{array}{l}-0.188^{+} \\
(-1.707)\end{array}$ & & \\
\hline $\mathrm{PB} * \mathrm{FC}$ & & & & & $\begin{array}{l}-0.024^{+} \\
(-1.823)\end{array}$ & $\begin{array}{l}-0.400^{*} \\
(-2.460)\end{array}$ & & \\
\hline MarOrient & & & & & & & $\begin{array}{c}0.055 \\
(0.442)\end{array}$ & $\begin{array}{c}0.281 \\
(0.209)\end{array}$ \\
\hline PB*MarOrient & & & & & & & $\begin{array}{c}0.186^{+} \\
(1.799)\end{array}$ & $\begin{array}{l}3.640^{* *} \\
(2.761)\end{array}$ \\
\hline Party_member & $\begin{array}{c}0.000 \\
(0.002)\end{array}$ & $\begin{array}{c}0.017 \\
(0.155)\end{array}$ & $\begin{array}{c}0.000 \\
(0.010)\end{array}$ & $\begin{array}{c}0.018 \\
(0.167)\end{array}$ & $\begin{array}{c}0.001 \\
(0.076)\end{array}$ & $\begin{array}{c}0.014 \\
(0.132)\end{array}$ & $\begin{array}{c}-0.000 \\
(-0.034)\end{array}$ & $\begin{array}{c}0.011 \\
(0.102)\end{array}$ \\
\hline $\mathrm{PC}$ & $\begin{array}{l}0.055^{* * *} \\
(6.158)\end{array}$ & $\begin{array}{l}0.708^{* * *} \\
(7.331)\end{array}$ & $\begin{array}{l}0.055^{* * *} \\
(6.115)\end{array}$ & $\begin{array}{l}0.698^{* * * *} \\
(7.276)\end{array}$ & $\begin{array}{l}0.055^{* * *} \\
(6.072)\end{array}$ & $\begin{array}{l}0.707^{* * * *} \\
(7.366)\end{array}$ & $\begin{array}{l}0.055^{* * * *} \\
(6.141)\end{array}$ & $\begin{array}{l}0.697^{* * *} \\
(7.331)\end{array}$ \\
\hline CPPCC & $\begin{array}{c}0.017^{+} \\
(1.683)\end{array}$ & $\begin{array}{c}0.149 \\
(1.276)\end{array}$ & $\begin{array}{l}0.017^{+} \\
(1.681)\end{array}$ & $\begin{array}{c}0.149 \\
(1.280)\end{array}$ & $\begin{array}{c}0.017^{+} \\
(1.730)\end{array}$ & $\begin{array}{c}0.153 \\
(1.315)\end{array}$ & $\begin{array}{c}0.017^{+} \\
(1.758)\end{array}$ & $\begin{array}{c}0.162 \\
(1.388)\end{array}$ \\
\hline Prior_gov_job & $\begin{array}{c}0.020^{+} \\
(1.733)\end{array}$ & $\begin{array}{c}0.274^{*} \\
(2.093)\end{array}$ & $\begin{array}{c}0.019 \\
(1.631)\end{array}$ & $\begin{array}{c}0.262^{*} \\
(1.978)\end{array}$ & $\begin{array}{c}0.018 \\
(1.594)\end{array}$ & $\begin{array}{c}0.273^{*} \\
(2.073)\end{array}$ & $\begin{array}{l}0.019^{+} \\
(1.710)\end{array}$ & $\begin{array}{c}0.270^{*} \\
(2.058)\end{array}$ \\
\hline Gender & $\begin{array}{l}-0.023^{* *} \\
(-2.795)\end{array}$ & $\begin{array}{l}-0.275^{* *} \\
(-3.027)\end{array}$ & $\begin{array}{l}-0.023^{* *} \\
(-2.750)\end{array}$ & $\begin{array}{l}-0.271^{* *} \\
(-2.975)\end{array}$ & $\begin{array}{l}-0.023^{* *} \\
(-2.809)\end{array}$ & $\begin{array}{l}-0.275^{* *} \\
(-3.037)\end{array}$ & $\begin{array}{l}-0.023^{* * *} \\
(-2.779)\end{array}$ & $\begin{array}{l}-0.277^{* *} \\
(-3.014)\end{array}$ \\
\hline CEO_age & $\begin{array}{c}-0.005 \\
(-0.205)\end{array}$ & $\begin{array}{c}-0.161 \\
(-0.677)\end{array}$ & $\begin{array}{c}-0.005 \\
(-0.214)\end{array}$ & $\begin{array}{c}-0.163 \\
(-0.682)\end{array}$ & $\begin{array}{c}-0.001 \\
(-0.045)\end{array}$ & $\begin{array}{c}-0.150 \\
(-0.623)\end{array}$ & $\begin{array}{c}-0.004 \\
(-0.194)\end{array}$ & $\begin{array}{c}-0.157 \\
(-0.657)\end{array}$ \\
\hline Edu_dummy & $\begin{array}{c}-0.010 \\
(-1.156)\end{array}$ & $\begin{array}{c}-0.066 \\
(-0.744)\end{array}$ & $\begin{array}{c}-0.011 \\
(-1.238)\end{array}$ & $\begin{array}{c}-0.075 \\
(-0.841)\end{array}$ & $\begin{array}{c}-0.007 \\
(-0.799)\end{array}$ & $\begin{array}{c}-0.059 \\
(-0.676)\end{array}$ & $\begin{array}{c}-0.010 \\
(-1.222)\end{array}$ & $\begin{array}{c}-0.075 \\
(-0.858)\end{array}$ \\
\hline Size_sales & $\begin{array}{l}0.043^{* * *} \\
(16.594)\end{array}$ & $\begin{array}{l}0.594^{* * *} \\
(16.946)\end{array}$ & $\begin{array}{l}0.042^{* * *} \\
(16.382)\end{array}$ & $\begin{array}{l}0.589^{* * *} \\
(16.937)\end{array}$ & $\begin{array}{l}0.042^{* * *} \\
(16.054)\end{array}$ & $\begin{array}{l}0.589^{* * *} \\
(16.844)\end{array}$ & $\begin{array}{l}0.043^{* * *} \\
(16.564)\end{array}$ & $\begin{array}{l}0.593^{* * *} \\
(16.895)\end{array}$ \\
\hline Firm_age & $\begin{array}{c}0.007 \\
(1.488)\end{array}$ & $\begin{array}{c}0.009 \\
(0.133)\end{array}$ & $\begin{array}{c}0.007 \\
(1.472)\end{array}$ & $\begin{array}{c}0.008 \\
(0.119)\end{array}$ & $\begin{array}{c}0.006 \\
(1.343)\end{array}$ & $\begin{array}{c}0.006 \\
(0.098)\end{array}$ & $\begin{array}{c}0.007 \\
(1.487)\end{array}$ & $\begin{array}{c}0.010 \\
(0.143)\end{array}$ \\
\hline ROS & $\begin{array}{l}0.126^{* * *} \\
(5.827)\end{array}$ & $\begin{array}{l}1.393^{* * *} \\
(5.503)\end{array}$ & $\begin{array}{l}0.126^{* * * *} \\
(5.813)\end{array}$ & $\begin{array}{l}1.396^{* * *} \\
(5.487)\end{array}$ & $\begin{array}{c}0.120^{* * *} \\
(5.903)\end{array}$ & $\begin{array}{l}1.323^{* * *} \\
(5.495)\end{array}$ & $\begin{array}{l}0.127^{* * *} \\
(5.871)\end{array}$ & $\begin{array}{l}1.411^{* * *} \\
(5.582)\end{array}$ \\
\hline _cons & $\begin{array}{c}-0.320^{* * * *} \\
(-3.366)\end{array}$ & $\begin{array}{c}-5.369^{* * * *} \\
(-5.186)\end{array}$ & $\begin{array}{c}-0.323^{* * * *} \\
(-3.369)\end{array}$ & $\begin{array}{c}-5.395^{* * *} \\
(-5.160)\end{array}$ & $\begin{array}{l}-0.290^{* *} \\
(-2.917)\end{array}$ & $\begin{array}{c}-5.026^{* * *} \\
(-4.809)\end{array}$ & $\begin{array}{c}-0.326^{* * *} \\
(-3.496)\end{array}$ & $\begin{array}{c}-5.345^{* * *} \\
(-5.340)\end{array}$ \\
\hline $\begin{array}{l}\text { Industry } \\
\text { Year }\end{array}$ & $\begin{array}{l}\text { Yes } \\
\text { Yes } \\
\end{array}$ & $\begin{array}{l}\text { Yes } \\
\text { Yes }\end{array}$ & $\begin{array}{l}\text { Yes } \\
\text { Yes }\end{array}$ & $\begin{array}{l}\text { Yes } \\
\text { Yes }\end{array}$ & $\begin{array}{l}\text { Yes } \\
\text { Yes }\end{array}$ & $\begin{array}{l}\text { Yes } \\
\text { Yes }\end{array}$ & $\begin{array}{l}\text { Yes } \\
\text { Yes }\end{array}$ & $\begin{array}{l}\text { Yes } \\
\text { Yes }\end{array}$ \\
\hline \multicolumn{9}{|c|}{ Random-effect Parameters } \\
\hline Var (Level-2) & $\begin{array}{c}0.003 * * * \\
(3.646)\end{array}$ & $\begin{array}{c}0.323 * * * \\
(3.922)\end{array}$ & $\begin{array}{c}0.003 * * * \\
(3.679)\end{array}$ & $\begin{array}{c}0.318 * * * \\
(3.981)\end{array}$ & $\begin{array}{c}0.003 * * * \\
(3.624)\end{array}$ & $\begin{array}{c}0.316 * * * \\
(3.94)\end{array}$ & $\begin{array}{c}0.003 * * * \\
(3.744)\end{array}$ & $\begin{array}{c}0.317 * * * \\
(4.234)\end{array}$ \\
\hline Var (Level-1) & $\begin{array}{l}0.178 * * * \\
(37.617)\end{array}$ & $\begin{array}{c}22.006 * * * \\
(30.729)\end{array}$ & $\begin{array}{c}0.178 * * * \\
(37.797)\end{array}$ & $\begin{array}{c}21.982 * * * \\
(30.911)\end{array}$ & $\begin{array}{c}0.178 * * * \\
(37.519)\end{array}$ & $\begin{array}{c}21.967 * * * \\
(30.715)\end{array}$ & $\begin{array}{c}0.178 * * * \\
(37.358)\end{array}$ & $\begin{array}{c}21.977 * * * \\
(30.434)\end{array}$ \\
\hline Var(MarOrient) & & & & & & & $\begin{array}{c}0.054 * * * \\
(21.792)\end{array}$ & $\begin{array}{c}0.056 * * * \\
(24.864)\end{array}$ \\
\hline $\begin{array}{l}\text { Sample Size } \\
\text { Level-1: Firm } \\
\text { Level-2: } \\
\text { Province }\end{array}$ & $\begin{array}{c}17690 \\
31\end{array}$ & $\begin{array}{c}17690 \\
31\end{array}$ & $\begin{array}{c}17690 \\
31\end{array}$ & $\begin{array}{c}17690 \\
31\end{array}$ & $\begin{array}{c}17690 \\
31\end{array}$ & $\begin{array}{c}17690 \\
31\end{array}$ & $\begin{array}{c}17690 \\
31\end{array}$ & $\begin{array}{c}17690 \\
31\end{array}$ \\
\hline
\end{tabular}

$t$ statistics in parentheses

${ }^{+} p<0.1,{ }^{*} p<0.05,{ }^{* *} p<0.01,{ }^{* * *} p<0.001$ 
Table 6 Treatment effects (PSM)

\begin{tabular}{|c|c|c|c|c|c|}
\hline Variable & Sample & Treated & Controls & Difference & T-stat \\
\hline \multicolumn{6}{|c|}{ 1.Matching on firm characteristics } \\
\hline \multirow[t]{2}{*}{ EnInvest } & Unmatched & 0.527 & 0.255 & 0.271 & $37.08 * * *$ \\
\hline & ATT & 0.527 & 0.344 & 0.183 & $20.26 * * *$ \\
\hline \multirow[t]{2}{*}{ LnEnInvest } & Unmatched & 6.090 & 2.621 & 3.469 & $42.12 * * *$ \\
\hline & ATT & 6.090 & 3.714 & 2.376 & $22.55 * * *$ \\
\hline \multicolumn{6}{|c|}{ 2.Matching on firm and entrepreneur characteristics } \\
\hline \multirow[t]{2}{*}{ EnInvest } & Unmatched & 0.524 & 0.259 & 0.265 & $30.71 * * *$ \\
\hline & ATT & 0.524 & 0.346 & 0.178 & $16.87 * * *$ \\
\hline \multirow[t]{2}{*}{ LnEnInvest } & Unmatched & 6.020 & 2.641 & 3.380 & $34.91 * * *$ \\
\hline & ATT & 6.020 & 3.684 & 2.336 & $19.03 * * *$ \\
\hline \multicolumn{6}{|c|}{ 3.Matching on firm and entrepreneur characteristics, industry and year dummy } \\
\hline \multirow[t]{2}{*}{ EnInvest } & Unmatched & 0.524 & 0.259 & 0.265 & $30.71 * * *$ \\
\hline & ATT & 0.524 & 0.357 & 0.168 & $15.79 * * *$ \\
\hline \multirow[t]{2}{*}{ LnEnInvest } & Unmatched & 6.020 & 2.641 & 3.380 & $34.91 * * *$ \\
\hline & ATT & 6.020 & 3.782 & 2.238 & $18.21 * * *$ \\
\hline
\end{tabular}

${ }^{+} p<0.1,{ }^{*} p<0.05,{ }^{* *} p<0.01,{ }^{* * * *} p<0.001$ 
Table 7 Instrument variable

\begin{tabular}{|c|c|c|c|}
\hline & $\begin{array}{l}(1) \\
\mathrm{PB}\end{array}$ & $\begin{array}{c}(2) \\
\text { EnInvest }\end{array}$ & $\begin{array}{c}(3) \\
\text { LnEnInvest }\end{array}$ \\
\hline PB & & $\begin{array}{l}0.741^{* * *} \\
(11.592)\end{array}$ & $\begin{array}{l}2.901^{* * *} \\
(12.847)\end{array}$ \\
\hline Union & $\begin{array}{l}0.334^{* * * *} \\
(44.898)\end{array}$ & & \\
\hline PB_Environ & $\begin{array}{l}0.384^{* * * *} \\
(25.927)\end{array}$ & & \\
\hline Party_member & $\begin{array}{l}0.163^{* * * *} \\
(24.668)\end{array}$ & $\begin{array}{c}-0.083^{* *} \\
(-3.115)\end{array}$ & $\begin{array}{l}-0.294^{* *} \\
(-3.116)\end{array}$ \\
\hline $\mathrm{PC}$ & $\begin{array}{l}0.083^{* * *} \\
(10.505)\end{array}$ & $\begin{array}{l}0.080^{* *} \\
(2.804)\end{array}$ & $\begin{array}{l}0.482^{* * * *} \\
(4.346)\end{array}$ \\
\hline СРPCC & $\begin{array}{l}0.019^{* * *} \\
(2.710)\end{array}$ & $\begin{array}{c}0.028 \\
(1.103)\end{array}$ & $\begin{array}{c}0.044 \\
(0.467)\end{array}$ \\
\hline Prior_gov_job & $\begin{array}{c}0.052^{* * * *} \\
(6.236)\end{array}$ & $\begin{array}{c}0.024 \\
(0.791)\end{array}$ & $\begin{array}{c}0.153 \\
(1.357)\end{array}$ \\
\hline Gender & $\begin{array}{c}-0.009 \\
(-1.244)\end{array}$ & $\begin{array}{l}-0.082^{*} \\
(-2.502)\end{array}$ & $\begin{array}{l}-0.257^{* *} \\
(-2.737)\end{array}$ \\
\hline CEO_age & $\begin{array}{c}0.010 \\
(0.655)\end{array}$ & $\begin{array}{c}-0.003 \\
(-0.040)\end{array}$ & $\begin{array}{l}-0.221 \\
(-1.115)\end{array}$ \\
\hline Edu_dummy & $\begin{array}{l}0.015^{* *} \\
(2.696)\end{array}$ & $\begin{array}{l}-0.052^{*} \\
(-2.255)\end{array}$ & $\begin{array}{c}-0.108 \\
(-1.456)\end{array}$ \\
\hline Size_sales & $\begin{array}{l}0.038^{* * * *} \\
(25.093)\end{array}$ & $\begin{array}{l}0.120^{* * * *} \\
(15.781)\end{array}$ & $\begin{array}{l}0.484^{* * * *} \\
(19.598)\end{array}$ \\
\hline Firm_age & $\begin{array}{c}-0.003 \\
(-0.675)\end{array}$ & $\begin{array}{l}0.032^{+} \\
(1.827)\end{array}$ & $\begin{array}{c}-0.014 \\
(-0.244)\end{array}$ \\
\hline ROS & $\begin{array}{c}0.013 \\
(1.071)\end{array}$ & $\begin{array}{c}0.534^{* * * *} \\
(8.931)\end{array}$ & $\begin{array}{l}1.377^{* * * *} \\
(8.535)\end{array}$ \\
\hline _cons & $\begin{array}{l}-0.659^{* * * * *} \\
(-11.075)\end{array}$ & $\begin{array}{c}-2.688^{* * * *} \\
(-9.829)\end{array}$ & $\begin{array}{l}-3.766^{* * * *} \\
(-4.527)\end{array}$ \\
\hline Industry & Yes & Yes & Yes \\
\hline Year & Yes & Yes & Yes \\
\hline Region & Yes & Yes & Yes \\
\hline $\begin{array}{l}N \\
\text { Wald test }\end{array}$ & 17652 & 17652 & $\begin{array}{l}17652 \\
0.233\end{array}$ \\
\hline Sargan-Hansen test & & $0.741^{* * * *}$ & $2.901^{* * * *}$ \\
\hline
\end{tabular}

$t$ statistics in parentheses

${ }^{+} p<0.1,{ }^{*} p<0.05,{ }^{* *} p<0.01,{ }^{* * *} p<0.001$ 
Table 8 The Party branch and ECSR (TCZ)

\begin{tabular}{|c|c|c|c|c|}
\hline & \multicolumn{2}{|c|}{ TCZ } & \multicolumn{2}{|c|}{ Non-TCZ } \\
\hline & (1) & (2) & (3) & (4) \\
\hline & EnInvest & LnEnInvest & EnInvest & LnEnInvest \\
\hline \multirow[t]{2}{*}{ PB } & $0.105^{\text {*** }}$ & $1.314^{* * *}$ & $0.095^{* * *}$ & $1.184^{* * *}$ \\
\hline & $(8.112)$ & $(7.956)$ & $(5.714)$ & $(5.544)$ \\
\hline \multirow[t]{2}{*}{ Party_member } & -0.003 & -0.022 & 0.005 & 0.094 \\
\hline & $(-0.230)$ & $(-0.172)$ & $(0.348)$ & $(0.532)$ \\
\hline \multirow[t]{2}{*}{ PC } & $0.060^{* * * *}$ & $0.743^{* * *}$ & $0.048^{*}$ & $0.636^{* *}$ \\
\hline & $(5.770)$ & $(6.292)$ & $(2.369)$ & (2.996) \\
\hline \multirow[t]{2}{*}{ СРPCC } & $0.023^{+}$ & 0.231 & -0.003 & -0.072 \\
\hline & (1.790) & (1.544) & $(-0.209)$ & $(-0.461)$ \\
\hline \multirow[t]{2}{*}{ Prior_gov_job } & 0.015 & $0.223^{+}$ & $0.029^{+}$ & $0.387^{+}$ \\
\hline & (1.187) & $(1.750)$ & $(1.812)$ & (1.726) \\
\hline \multirow[t]{2}{*}{ Gender } & $-0.020^{*}$ & $-0.271^{*}$ & $-0.027^{+}$ & $-0.271^{+}$ \\
\hline & $(-1.995)$ & $(-2.535)$ & $(-1.789)$ & $(-1.650)$ \\
\hline \multirow[t]{2}{*}{ CEO_age } & 0.021 & 0.159 & $-0.065^{+}$ & $-0.934^{*}$ \\
\hline & $(0.667)$ & $(0.474)$ & $(-1.708)$ & $(-2.505)$ \\
\hline \multirow[t]{2}{*}{ Edu_dummy } & -0.010 & -0.055 & -0.009 & -0.088 \\
\hline & $(-1.149)$ & $(-0.593)$ & $(-0.646)$ & $(-0.633)$ \\
\hline \multirow[t]{2}{*}{ Size_sales } & $0.041^{* * * *}$ & $0.576^{* * * *}$ & $0.046^{* * * *}$ & $0.635^{* * * *}$ \\
\hline & (14.734) & (14.942) & $(10.285)$ & (10.678) \\
\hline \multirow[t]{2}{*}{ Firm_age } & 0.006 & 0.011 & 0.011 & 0.026 \\
\hline & (1.177) & $(0.188)$ & $(0.919)$ & $(0.163)$ \\
\hline \multirow[t]{2}{*}{ ROS } & $0.155^{* * * *}$ & $1.635^{* * *}$ & 0.055 & $0.796^{+}$ \\
\hline & $(6.586)$ & $(6.306)$ & $(1.635)$ & (1.956) \\
\hline \multirow[t]{2}{*}{ _cons } & $-0.463^{* * *}$ & $-6.502^{* * * *}$ & -0.197 & $-3.010^{+}$ \\
\hline & $(-3.711)$ & $(-4.733)$ & $(-1.253)$ & $(-1.942)$ \\
\hline Industry & Yes & Yes & Yes & Yes \\
\hline Year & Yes & Yes & Yes & Yes \\
\hline$N$ & 12473 & 12473 & 5217 & 5217 \\
\hline
\end{tabular}

${ }^{+} p<0.1,{ }^{*} p<0.05,{ }^{* *} p<0.01,{ }^{* * *} p<0.001$ 


\begin{tabular}{|c|c|}
\hline Variable & Definition \\
\hline \multicolumn{2}{|c|}{ Dependent variables } \\
\hline EnInvest & $\begin{array}{l}\text { A dummy variable, which equals to one if the firm has any environmental } \\
\text { investment at the time of the survey and equals to zero otherwise. }\end{array}$ \\
\hline lnEnInvest & The log transformation of the sum of the environmental investments and one. \\
\hline \multicolumn{2}{|c|}{ Independent Variable } \\
\hline PB & $\begin{array}{l}\text { A dummy variable, it is equal to one if a focal firm has already set up a Party } \\
\text { branch within the firm in the survey year, and it is equal to zero otherwise. }\end{array}$ \\
\hline \multicolumn{2}{|c|}{ Moderating Variables } \\
\hline CenGovern & $\begin{array}{l}\text { It is equal to one if the entrepreneur reported himself/herself in the survey that } \\
\text { he/she was the final decision-maker. }\end{array}$ \\
\hline $\mathrm{FC}$ & $\begin{array}{l}\text { A dummy variable that equals one if the firm does not pay any dividend in the } \\
\text { survey year, and it equals to zero, otherwise. }\end{array}$ \\
\hline MarOrient & $\begin{array}{l}\text { The proportion of total fixed investment in a province that comes from private } \\
\text { enterprises. Bigger value means the better operational environment for private } \\
\text { firms. }\end{array}$ \\
\hline \multicolumn{2}{|c|}{$\begin{array}{l}\text { Control Variables } \\
\text { Owner characteristics }\end{array}$} \\
\hline Party member & $\begin{array}{l}\text { A dummy variable that equals to one if the firm's owner is a member of the Chinese } \\
\text { Communist Party at the time of the survey and equals to zero if otherwise. }\end{array}$ \\
\hline Prior_gov_job & $\begin{array}{l}\text { A dummy variable that equals to one if the firm's owner used to work for either the } \\
\text { government or the Party before founding the firm and equals to zero if otherwise. }\end{array}$ \\
\hline $\mathrm{PC}$ & $\begin{array}{l}\text { A dummy variable that equals to one if the firm's owner is a member of the } \\
\text { People's Congress at the time of the survey and equals to zero if otherwise. }\end{array}$ \\
\hline СPPCC & $\begin{array}{l}\text { A dummy variable that equals to one if the firm's owner is a member of the } \\
\text { People's Consultative Conference at the time of the survey and equals to zero if } \\
\text { otherwise. }\end{array}$ \\
\hline Gender & $\begin{array}{l}\text { A dummy variable that equals to one if the entrepreneur is a female and equals to } \\
\text { zero if otherwise }\end{array}$ \\
\hline CEO_age & Log of the age of the entrepreneur at the time of the survey \\
\hline Edu_dummy & $\begin{array}{l}\text { A dummy variable that equals to one if the entrepreneur has obtained a bachelor's } \\
\text { degree at the time of the survey and equals to zero if otherwise }\end{array}$ \\
\hline \multicolumn{2}{|c|}{ Firm characteristics } \\
\hline Size_sales & The total sales of the firm in the survey year \\
\hline Firm_age & The age of the firm at the time of the survey \\
\hline ROS & The return over sales of the firm \\
\hline \multicolumn{2}{|c|}{ Instrumental Variables } \\
\hline Union & $\begin{array}{l}\text { A dummy variable that equals to one if the firm has a labor union at the time of the } \\
\text { survey. }\end{array}$ \\
\hline PB-Environ & $\begin{array}{l}\text { The average ratio of private firms that already setup party branches in the survey } \\
\text { year calculate by other surveyed firms in the same city }\end{array}$ \\
\hline
\end{tabular}


Appendix Table 2 Post-hoc probing test

\begin{tabular}{|c|c|c|c|}
\hline (1) & (2) & (3) & $\begin{array}{c}\text { (4) } \\
\text { (nFnInve }\end{array}$ \\
\hline EnInvest & & & \\
\hline \multicolumn{4}{|c|}{ Panel A: for the interaction term PB* CenGovern } \\
\hline \multicolumn{2}{|c|}{ CenGovern=1 } & \multicolumn{2}{|c|}{ CenGovern $=0$} \\
\hline $\begin{array}{c}0.272^{* * * *} \\
(9.728)\end{array}$ & $\begin{array}{l}1.356^{\text {***** }} \\
(12.404)\end{array}$ & $\begin{array}{c}0.176^{\text {**** }} \\
(3.354)\end{array}$ & $\begin{array}{c}0.717^{* * * *} \\
(3.599)\end{array}$ \\
\hline
\end{tabular}

Panel B: for the interaction term $P B^{*} F C$

\begin{tabular}{|c|c|c|c|}
\hline \multicolumn{2}{|c|}{$\mathrm{FC}=1$} & \multicolumn{2}{|c|}{$\mathrm{FC}=0$} \\
\hline $\begin{array}{c}0.243^{* * *} \\
(5.436)\end{array}$ & $\begin{array}{c}0.964^{* * *} \\
(5.760)\end{array}$ & $\begin{array}{c}0.267^{* * * *} \\
(9.207)\end{array}$ & $\begin{array}{l}1.367^{* * *} \\
(12.018)\end{array}$ \\
\hline \multicolumn{4}{|c|}{ Panel C: for the interaction term $P B^{*}$ MarOrient } \\
\hline \multicolumn{2}{|c|}{ High MarOrient } & \multicolumn{2}{|c|}{ Low MarOrient } \\
\hline $\begin{array}{c}0.295^{* * * *} \\
(8.793)\end{array}$ & $\begin{array}{l}1^{1.598} 8^{* * *} \\
(11.972)\end{array}$ & $\begin{array}{c}0.221^{* * *} \\
(6.489)\end{array}$ & $\begin{array}{c}0.909^{\text {*** }} \\
(7.062)\end{array}$ \\
\hline 17690 & 17690 & 17690 & 17690 \\
\hline
\end{tabular}

$t$ statistics in parentheses

${ }^{+} p<0.1,{ }^{*} p<0.05,{ }^{* *} p<0.01,{ }^{* * *} p<0.001$ 